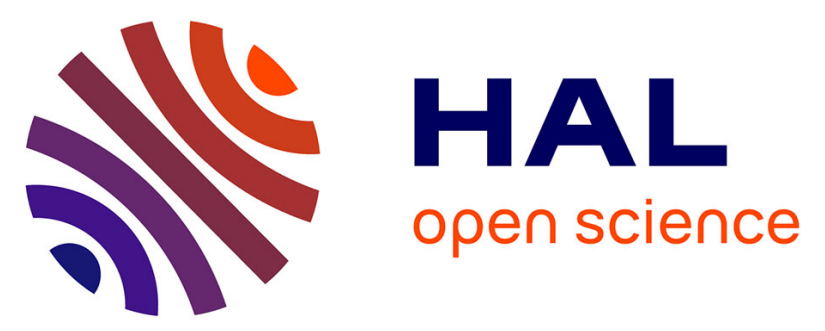

\title{
Comparative analysis of wucai Chinese porcelains using mobile and fixed Raman microspectrometers
}

Philippe Colomban, Florian Ambrosi, Anh-Tu Ngo, Ting-An Lu, Xiong-Lin Feng, Stephen Chen, Chung-Lit Choi

\section{- To cite this version:}

Philippe Colomban, Florian Ambrosi, Anh-Tu Ngo, Ting-An Lu, Xiong-Lin Feng, et al.. Comparative analysis of wucai Chinese porcelains using mobile and fixed Raman microspectrometers. Ceramics International, 2017, 43 (16), pp.14244-14256. 10.1016/j.ceramint.2017.07.172 . hal-01581917

\section{HAL Id: hal-01581917 https://hal.sorbonne-universite.fr/hal-01581917}

Submitted on 5 Sep 2017

HAL is a multi-disciplinary open access archive for the deposit and dissemination of scientific research documents, whether they are published or not. The documents may come from teaching and research institutions in France or abroad, or from public or private research centers.
L'archive ouverte pluridisciplinaire HAL, est destinée au dépôt et à la diffusion de documents scientifiques de niveau recherche, publiés ou non, émanant des établissements d'enseignement et de recherche français ou étrangers, des laboratoires publics ou privés. 


\title{
Comparative analysis of wucai Chinese porcelains using mobile and fixed Raman microspectrometers
}

Philippe Colomban, ${ }^{1}$ Florian Ambrosi ${ }^{1}$, Anh-Tu Ngo ${ }^{1}$, Ting-An Lu ${ }^{1}$, Xiong-Lin Feng ${ }^{2}$, Stephen Chen ${ }^{3}$,Chung-Lit Choi ${ }^{3}$

${ }^{1}$ Sorbonne Universités, UPMC Univ. Paris 06, MONARIS UMR8233, CNRS, 4 Place Jussieu, 75005 Paris, France

${ }^{2}$ Ancient Ceramic Research Laboratory, Chinese Academy of Science, Beijing, China

${ }^{3}$ Royal Heritage, Suit 212 Building 18, Hong Kong Science Park, Shatin, Hong Kong

\begin{abstract}
Three porcelain shards representative of wucai (Famille verte, Famille rose and fencai), enamelled wares from Kangxi, Yongzheng and Qianlong reigns have been studied using fixed instruments (optical microscope, EDS-SEM and Raman microspectrometer) in order to identify the amorphous and crystalline phases in the glaze, body and the different enamels. A comparison is made between the information collected with portable Raman set-ups excited with 532 and $785 \mathrm{~nm}$ lasers and equipped of sophisticated optics. Emphasis is put on the detection of pigments and opacifiers, in particular arsenic-based phases in blue coloured areas, in relation with the use of cobalt ores originated from European or China. The mobile Raman set-up excited with green laser and equipped with a high magnification (x200) ultra long working distance microscope objective allows the identification of all the phases, as for the fixed instrument excited with blue $457 \mathrm{~nm}$ laser line. Confirmation of the identified phases is made by SEM-EDS. The old technologies are discussed and compared to those used to produce $18^{\text {th }}$ century French soft paste porcelains and Limoges enamels.
\end{abstract}

Keywords: B: impurities; B: spectroscopy; C: colour; D: glass arsenic 


\section{Introduction}

In China, the early reigns of the Qing Dynasty constituted a brilliant period with the development of innovative support for the craft industry. A significant breakthrough in the enamel technology was achieved at that time, with the spread of enamel work on glass, metal and ceramic. Emperors such as Kangxi, Yongzheng and Qianlong imposed their personal charisma, living taste and love of technical innovations. During Kangxi's reign, the Famille verte family, known in Chinese as wucai (five colours) developed using green, yellow, red and turquoise enamels on porcelain decorated with underglaze blue cobalt [1]. Later, cobalt-based blue overglaze was used. At the end of Kangxi's reign, the so-called Famille rose (also called fencai or yangcai, meaning foreign colours) appeared. What is meant by 'foreign' remains unclear: what is due to European productions in the use of such a palette, was the technology based on European receipts, or were the raw materials or the enamel colours imported? Famille rose wares are characterized by a red to rose enamel based upon colloidal gold, a technique first developed in Europe for ruby glass by Perrot [2-4], and then for the camaïeu decor of many soft-paste porcelains [5]. Both Chinese and European (Jesuits) historical records point out the transfer of know-how and craftsmen from France to the Qing Imperial Court regarding astronomy, mathematics, ... and enamelling technology at the turn of the seventeenth and eighteenth centuries [610]. Mobile (on site) and fixed laboratory Raman analyses of a large corpus of European [5,11-13] and Chinese enamelled precious artefacts [14] in addition to elemental composition measurements of some shards [15-23] showed that Chinese craftsmen used different types of cobalt sources including arsenicrich cobalt ores similar to those used in Europe for soft-paste porcelain [5,11] and Limoges enamels [24], and manganese- and/or iron-rich ores of Asian origins [16-18,25] to make blue decorations. Chinese craftsmen also tried to imitate the visual aspect of European realistic paintings by the development of a rich palette and graduate hues. Major characteristics of these 'new' enamelled objects were the use of opaque enamels, with well-defined border, as in European oil paintings, contrarily to 'classic' Chinese ceramic decoration that looks like watercolour technique. However, data are limited and more work is needed to get a representative view of the enamelling technologies and raw materials used in Europe at the turn of the $17^{\text {th }}$ century and in China especially during Kangxi's to Qianlong's reigns, at the height of colourful porcelains.

Recent studies demonstrated that useful information can be obtained by non-invasive mobile techniques, based on portable XRF and Raman spectroscopies [14,24-29]. The great advantages of Raman microspectroscopy are: i) its non-invasive character that allows studying very precious items, ii) the availability of high sensitivity mobile instruments that permit the measurements of many objects per day in exhibition, ancient tombs or storage rooms, iii) a great efficiency in the identification of many colouring agents, even at low concentration and iv) the possibility of very local and in-depth analysis. Thus, the technique offers the possibility to collect statistically representative information by 
studying the very rare and precious items belonging to famous private or public collections, such as objects assigned to the imperial workshop production.

The blue decoration has attracted most attention of Chinese ceramic scholars. There are three procedures to obtain blue enamels: addition of cobalt ions or of cobalt-hosting pigments [25], dispersion of lapis lazuli grains [30,31] or, presently, of vanadium-doped zircon powders [32]. The relatively limited number of cobalt sources [25,33], especially accessible to China in the past, along with the footprint compositions of the cobalt ores (minor components and traces), makes it possible to classify - and attribute - the blue colour precursors in Chinese artefacts to their region and time of production [15-20,22-25]. Such attributions were mainly inferred by (micro/macro) destructive elemental analysis that should be only performed on fragments and not on the precious artefacts. The problem does not only concern enamelled pottery but also enamelled glass objects [33-36]. A combined analysis of 'reference' samples with different techniques is necessary to assess the limits of the mobile Raman spectroscopy for the study of enamelled Chinese porcelains. However, artefacts assigned by the imperial workshop production under the guidance of European Jesuits are rare and highly prized. Non-invasive analytical procedures are thus mandatory; in addition they have to be rapid as the access time to the artefacts is very limited.

We present here a comprehensive study of three shards, each of them being representative of the main Qing Imperial porcelain production: a wucai/doucai shard with blue underglaze (Famille verte), a wucai (Famille rose) shard representative of Yongzheng's reign production and $a$ shard with contrasted colour (fencai), representative of Qianlong's reign production (Figs 1-3). These shards have been found during road construction work at the Imperial Palace (implying Imperial origin). Porcelain bodies and the different coloured areas have been analysed by optical microscopy, SEM-EDS and Raman microspectroscopy under different laser excitations and with both fixed and mobile instruments.

\section{Materials and experimental methods}

\subsection{Methods}

The shards were simply cut with a diamond-rich bronze saw (Minitom, Struers) and the surface and cross sections were observed with an optical microscope (BX51 Olympus Microscope). Polishing liquid residues and soil pollution can generate a strong fluorescence which is detrimental to Raman analyses; therefore they have to be washed off completely before and after the cutting. However most of the fluorescence observed on shards arises from the biological film which developed during their stay in the soil. A few $\mathrm{mW} / \mu \mathrm{m}^{2}$ green laser illumination (or less for blue excitation) is usually sufficient to clean the surface from its biologic film and hence to decrease/eliminate the fluorescence background.

Raman microspectroscopy analysis were made using a HR800 LabRam spectrometer (Horiba JobinYvon) coupled to a BX Olympus microscope with different long and short working distance 
objectives, equipped with an $\mathrm{Ar}^{+}$ion laser (457 nm line is used, this laser line is well convenient for the study of ceramics and glass) and a Peltier Effect cooled CCD detector. The analysis was conducted with Olympus x10, and x100, Nikon x50 and Mitutoyo x200 ultra long working distance objectives in order to obtain a representative characterization of the different phases at different scales. Due to the use of $600 \mathrm{l} / \mathrm{mm}$ grating the resolution is only $\sim 2 \mathrm{~cm}^{-1}$. Samples are examined on the top and on the section in order to collect representative spectra of all the phases. More than 20 spectra have been collected for each sample. The power of illumination at the sample ranges between 1 and $2 \mathrm{~mW}$. Typical counting time ranges between 1 and 5 minutes. Five to ten accumulations are made in order to eliminate cosmic events and increase the signal-to-noise ratio.

Raman spectra were also recorded with the HE532 and HE785 Horiba Jobin-Yvon mobile spectrometers equipped with $300 \mathrm{~mW}$ laser at 532 and $785 \mathrm{~nm}$ (respectively Ventus Laser Quantum, Stockport and Process Instruments Inc., Salt Lake City) and ULWD microscope objectives, as previously described [5]. The laser and the spectrometer are fibre optically connected to the remote Superhead ${ }^{\circledR}$ put on a heavy stage with XYZ micrometric displacement. Special x200 Mitutoyo and x50 Nikon and x40 IR optimised Olympus ULWD objectives were used. Due to the huge sensibility of HE spectrometers and the high power of illumination (5 to $20 \mathrm{~mW}$ at the sample, $<5 \mathrm{~mW}$ intensity being used for dark/heavy coloured enamels), counting times are generally reduced to a few seconds and 10 to 100 accumulations are made. However, due to the use of optics fibres and filters to reject the Rayleigh line, the background is important and has a complex shape (see further). More than 20 spectra have been collected with each instrument for each sample. Note that because of the shorter wavelength, the HE532 instrument is much bigger and heavier than the HE785 one.

Elemental composition was obtained under a JEOL 5410LV SEM-EDX using an acceleration voltage of $20 \mathrm{kV}$. The sample was wrapped with a carbon-rich tape with a small window for the area (Fig. S1, Supplementary Material) to be analyzed in order to limit detrimental charge effects. Evacuation of the charge is not as good as with the application of a conducting coating ( $\mathrm{C}$ or Au-Pd) but preserves the samples. Furthermore, due to the difficulty of recognizing specific coloured areas on SEM images, the delimitation of the window helps to correlate Raman and SEM-EDS measurements. EDS spectra were recorded using $x 400$ magnification in order to measure the composition on a submicronic area, similar to that probed by high magnification Raman technique. It is important to note that contrarily to glass, pigment-coloured enamels are highly heterogeneous at the scale of a few micron. Consequently, mean composition as determined e.g. by X-ray fluorescence or other techniques probing a large volume $\left(\mathrm{mm}^{2}\right)$ do not reflect the true composition of the different phases. Furthermore, due to the fluxing properties of lead-rich composition reactions with the substrate are very developped and induce a composition gradient from the body-glaze interface to the sample surface. Quantitative elemental analysis (oxide) was done using the ZAF calculation method as implemented in the Iridium Ultra software. The validity of measurements was monitored by applying the same procedure to certified glass-reference samples: "Corning Museum B, C and D" and American "National Bureau of Standard 
(NBS 620)", as usual [36]: the error is below 10\%, below 5\% for most of the measured elements. Note, boron element cannot be measured. Correspondence between areas measured by Raman scattering and probed by EDS are illustrated in Fig. S1.

\subsection{Samples}

Figs 1 to 3 show the studied shards and some details of the enamelled surface and sections.

These shards are thought to have being produced for the imperial court, respectively during the Kiangxi (1715-1722), Yongzheng (1723-1735) and Qianlong (1735-1796) reigns. They are deposited in the Ancient Porcelain Research Laboratory of the Chinese Academy of Science in Peking with label number QSD7, QSD2 and QSD1 respectively.

Fig. 1 shows a Famille verte porcelain shard (also called wucai ware) with a typical garden landscape decoration (with "Great Qing Dynasty Kangxi Reign Creation" mark). The blue ornament is drawn on the body under the glaze (see section shown in Fig. 1d; in 1c the mark can be observed through the overglaze). The red, the black (Figs $1 \mathrm{~h} \mathrm{\&} \mathrm{g)} \mathrm{and} \mathrm{the} \mathrm{green} \mathrm{(Fig.} \mathrm{1e)} \mathrm{have} \mathrm{been} \mathrm{deposited} \mathrm{over} \mathrm{the}$ glaze. The glaze thickness ranges between 100 and $600 \mu \mathrm{m}$, having the thicker layer being observed in the internal rim (Figs $1 \mathrm{~b} \& \mathrm{~d}$ ). The thickness of green (Fig. 1e), red (Figs 1g, note the red enamel close to g label) and black (Fig. 1a) overglazes ranges between 10 and $30 \mu \mathrm{m}$.

Fig. 2 shows a Famille rose-like porcelain with gilding (Fig. 2 a, a' and b), also called fencai ('powder colours') or ruan cai ('soft colours') in Chinese. The different coloured areas are delimited with a black line (Fig. 2c). The blue overglaze shows many cracks (Fig. 2d). The rose-red areas are very rough without any gloss indicating an inadequate firing/glazing procedure. The thickness of the coloured glaze is close to $300 \mu \mathrm{m}$ (Figs 2 e \& f). The thickness of the blue decoration is about $50 \mu \mathrm{m}$.

Fig. 3 shows an example of painted opaque enamelled object: as fencai, or softcai, which was derived from falangcai ware [14] this ware is made of opaque blue, red, white, green and yellow glazed areas delimited with narrow black lines. Sections (Figs 3 d, e and f) show that blue and red areas are overglazed but diffuse largely in the glaze. Although the quality of the gloss is very good for the red colour, in many places yellow areas and almost everywhere blue, white and mixed red-white colours are rough without gloss, indicating an inadequate enamel composition or firing procedure. The thickness of the colourless glaze is approximately $300 \mu \mathrm{m}$ and that of the opaque overglaze is reduced to $100 \mu \mathrm{m}$ (Fig. $3 \mathrm{~d}$, e and g).

\section{Results}

\subsection{Analysis with fixed instruments}

Figs 4 to 6 and 8 show representative as-recorded Raman spectra acquired with the fixed instrument. Representative EDS spectra are shown in Figs 5, 7 and 9. For comparison, representative Raman spectra recorded with HE532 and HE785 mobile spectrometers are shown in Fig. 10 and 11, respectively. 


\section{Body}

Fig. 4 (left part) compares representative spectra collected on the porcelain bodies with $\mathrm{x} 10$ (the large spot mediates the information but the signal intensity is weaker) and x100 ULWD objectives (local analysis, spot waist $<5 \mu \mathrm{m}$ ). A well defined mullite signature is observed (peaks at ca. 310, 415, 600, 955 and $1130 \mathrm{~cm}^{-1}$ [37,38]) as usual for hard paste porcelain [39]. Due to the high orientational disorder of $\mathrm{SiO}_{4}$ tetrahedra and the $\mathrm{Al} / \mathrm{Si}$ site occupation disorder, many Raman peaks of crystalline mullite, in particular those involving bending modes, are very large ; therefore, it is rather difficult to separate the contribution of the mullite phase from that of the glassy aluminosilicate matrix [37] surrounding the mullite needles [40]. However, it is possible to roughly estimate their relative contents by comparing the intensity of the ca. 1130 and $960 \mathrm{~cm}^{-1}$ peaks versus the ca. $800 \mathrm{~cm}^{-1}$ one. It appears that the highest amount of mullite is measured in the Famille verte sample.

A carbon doublet (1350-1600 $\left.\mathrm{cm}^{-1}\right)$ is only detected in the "Qianlong" body. This indicates that this sample was fired with stronger reducing conditions than the others (and/or the addition of an organic medium to the kaolin-feldspar-quartz mixture).

Note the very narrow ro-vibrational peak at ca. $1555 \mathrm{~cm}^{-1}$ characteristic of $\mathrm{O}_{2}$ gas soaked in the closed porosity (bubbles) observed in many spectra of Famille verte and Famille rose shards. The $\mathrm{O}_{2}$ gas signature is enhanced by the multireflection of the light at the bubble-porcelain matrix interface. In some spots the signature of $\alpha$ quartz indicates relics of un-dissolved grains (peaks at ca. 190, 260, 355, $395,460,692,800$ and $1160 \mathrm{~cm}^{-1}$ [41]). Downshift of the ca. $460 \mathrm{~cm}^{-1}$ peak up to $455 \mathrm{~cm}^{-1}$ arises from the compression of (small) quartz grains by the mullite-rich matrix due to the much lower thermal expansion of mullite than that of quartz $\left(464 \mathrm{~cm}^{-1}\right.$ usually for stress-free quartz grains) $[42,43]$. In accordance with the higher mullite amount the compressive shift is maximal in the Famille verte sample.

Fig. 4( right part) shows representative EDS spectra. The elemental composition calculated from EDS data is given in Table S1. Traces of iron are measured, as usual $\left(\sim 0.2 \mathrm{wt} \% \mathrm{Fe}_{2} \mathrm{O}_{3}\right)$. In agreement with the observation of unreacted calcite relics $\left(1085 \mathrm{~cm}^{-1}\right.$ peak) higher calcium content is measured in the Qianlong ware ( $0.5 \mathrm{wt} \%$ to be compared to $0.15 \mathrm{wt} \%$ for the others). Traces of sulphur and chlore are detected, minimal levels being observed in the Famille verte shard that may indicate a higher firing temperature. Traces of phosphate $\left(\sim 1 \mathrm{wt} \% \mathrm{P}_{2} \mathrm{O}_{5}\right)$ are noted in the Famille verte and Qianlong wares. Phosphorus contamination from the soil cannot be excluded.

\section{Glaze}

Fig. 5a) shows representative Raman spectra of the glaze fired with the body in the case of the Famille verte shard. The spectrum shows some similarities with that of the body due to rather analogous compositions (potash-lime aluminosilicate). Nonetheless, , 'narrow' peaks characteristic of mullite (at ca. 955,1035 and $1130 \mathrm{~cm}^{-1}$ ) which were observed on the body spectrum (Fig. 4) are not observed on the glaze one. The ca. $507 \mathrm{~cm}^{-1}$ and $462 \mathrm{~cm}^{-1}$ peaks observed in one of the glaze spectra indicate un- 
dissolved feldspar and quartz grains, respectively [41]. Note that if the zone probed by EDS measurements integrated quartz or feldspar grains, silicon and aluminium level would be increased, respectively. Lead-based overglazes show a Si-O stretching component below $1000 \mathrm{~cm}^{-1}$ [44].

An example of glaze composition measured close to the body-glaze interface is reported in Table $1 \mathrm{~b}$. A small contamination with $\mathrm{PbO}$ is measured.

\section{Famille verte enamels}

Fig. 5 shows representative Raman spectra recorded on the different coloured areas of the Famille verte shard. The red enamel exhibits the hematite characteristic signature [45,46]. The peaks bandwidth varies from spot to spot. The narrow peaks indicate a hematite composition very close to pure $\alpha \mathrm{Fe}_{2} \mathrm{O}_{3}$ whereas the broader ones reveal partial substitution of $\mathrm{Fe}$ ions by $\mathrm{Ti}$ or $\mathrm{Al}$ ones [46]. This may indicate either the use of natural heterogeneous ores or the mixing of ores from different sources. The Raman spectrum of the blue glaze is similar to that of the colourless one, except the flatter baseline shape due to the colour absorption in the red range. This is consistent with coloration by complete dissolution of $\mathrm{Co}^{2+}$ ions in the aluminosilicate glassy matrix [45]. The spectra recorded on black lines show a broad signature with maximum at ca. $600 \mathrm{~cm}^{-1}$ characteristic of a spinel-type compound $[46,47]$. Variations of the Raman signatures of spinels with different compositions being very limited, it is not possible to assign the spectrum more precisely. Raman spectra recorded on the green area are similar to those of blue and colourless glazes, indicating a coloration without use of pigment (ions only), the so-called "couleurs transparentes".

EDS spectra recorded on the blue glaze, on the top (Fig. 5b1) or on the section (Fig. 5b2, lead-poor, very close to the body, see Fig.1d) show the characteristic Fe-Co doublet observed when iron-cobalt ores are used as cobalt source $[18,47] . \mathrm{K}_{\beta} \mathrm{Fe}$ and $\mathrm{K}_{\alpha}$ Co peaks are very close and our instrumental resolution is not sufficient to discriminate between the two contributions on the spectrum. The glaze colour and comparison of the peak intensities are necessary to identify the main contribution. Confirmation is given by ZAF calculations (Table 1). The presence of lead detected in the top-surface (Fig. 5b1, a few wt\% $\mathrm{PbO}$ ) arises from contamination of the glaze surface with the overglazing green and red areas because of the high volatility of $\mathrm{PbO}$ above $900^{\circ} \mathrm{C}$. A small lead amount $(\sim 2 \mathrm{wt} \% \mathrm{PbO}$, Table 1a) is detected in the section (Fig. 5b2) measurement in agreement with the drawing of the blue line directly on the body (Fig. 1d), then covered by the glaze layer. No traces of arsenic or manganese are detected (Table 1a). A Manganese peak is clearly observed associated to that of iron, copper, nickel, tin and zinc for the black lines (Fig. 5b3), in agreement with the spinel signature observed by Raman microspectrometry (Fig. 5a). EDS spectra recorded on green areas (Fig. 5b4) show small traces of copper $(0.1 \% \mathrm{wt})$ but a rather high level of tin $(1.5 \% \mathrm{wt})$ : the green colour is not due to copper ions but to the dispersion of a yellow pigment in the blue coloured glaze, in agreement with the cobalt content $(0.1 \% \mathrm{wt})$. The poor quality of the spectrum is due to the very corrugated and cracked surface of the overglaze (Fig. 1e). Chlore traces seem to be also present in blue and black areas (addition of $\mathrm{NaCl}$ in the glaze slurry?). 


\section{Famille rose enamels}

Fig. 6 shows representative Raman spectra. A strong narrow peak at ca. $820 \mathrm{~cm}^{-1}$, characteristic of arsenate $[14,21,24,48,49]$ is found on blue and white areas. The peak position shifts a little, likely because of the partial substitution of lead with calcium or sodium [50] or due to the superimposition of $\mathrm{CoSiO}_{4}$ spectrum, the $\mathrm{Si}-\mathrm{O}$ stretching doublet of the olivine structure peaking at about the same wavenumber [51]. The intensity of the Si-O stretching band tends to be much lower than that of As-O because of the smaller polarisability and the lower number of electrons involved in the bond. Consequently, an intense ca. $820 \mathrm{~cm}^{-1}$ peak indicates an arsenate phase. The characteristic signature of the lead-based pyrochlore yellow pigment (ca. $140 \mathrm{~cm}^{-1}$ peak) is measured on yellow and green areas. Even though some correlations have been claimed in the literature between the wavenumber characteristics and the composition of the $\mathrm{Pb}_{2}[\mathrm{Sb} / \mathrm{Sn} / \mathrm{Fe} / \mathrm{Zn}]_{2} \mathrm{O}_{7-\delta}$ pyrochlore solid solution ( $\mathrm{Sb} / \mathrm{Sn} / \mathrm{Fe} / \mathrm{Zn}$ ions partial substitution) [52-58], it is difficult to determine the exact composition from the sole Raman spectrum. Relative intensities of the stretching modes characteristic of Sn-O $\left(\sim 450 \mathrm{~cm}^{-}\right.$ ${ }^{1}$ ) or $\mathrm{Sb}-\mathrm{O}\left(\sim 508 \mathrm{~cm}^{-1}\right)$ bonds can be used to discriminate between the different types of pyrochlore solid solutions. The position of the low wavenumber mode $\left(135-140 \mathrm{~cm}^{-1}\right)$ arising from $\mathrm{Pb}$ ions translational modes depends much more from the firing temperature, structure distortion and nonstoichiometry. The spectra recorded on the red area are poor because of the high roughness of the surface and because of the huge light absorption by the gold nanoparticles (see further). The Hematite spectrum seems however detected in some places (peaks at $\sim 200,275,330$ and $1320 \mathrm{~cm}^{-1}$, Fig. 6b). Either it results from a pollution or maybe an iron salt was used as redox agent to precipitate colloidal gold from the acid liquid precursor. A carbon doublet is observed as well as anatase traces $\left(\mathrm{TiO}_{2}, \mathrm{Fig}\right.$. 6a). Because of the high roughness it is difficult to determine if the carbon is dispersed in the glaze or if the carbon peaks arise from the heating of dust and organic residues trapped in surface defects. The spectra recorded on black lines show a mixture of carbon black and spinel phases $\left(640 \mathrm{~cm}^{-1}\right.$ peak). In rare spots spectra can be measured on gilded areas. Traces of pyrochlore (150, 288 and $\left.520 \mathrm{~cm}^{-1}\right)$ and of a carbonate phase $\left(1090 \mathrm{~cm}^{-1}\right.$ narrow peak assigned to siderite $\mathrm{FeCO}_{3}$ [59]) are also detected.

The corresponding EDS spectra are presented in Fig. 7 and Table 1a. Gold (92 wt \% Au) is alloyed with a small amount of silver ( 2.5 wt \%, Table 1a) and traces of iron are measured in gilded areas (Figs 2, 7 and S1, Table 1a) as usually for gilded ceramics [27,60], silver alloying probably promoting the ceramic-metal adhesion. Other peaks arise from the contribution of the porcelain substrate: $\mathrm{SiO}_{2}$ : $3.7 \mathrm{wt} \%, \mathrm{Al}_{2} \mathrm{O}_{3}: \sim 1 \mathrm{wt} \%$; we see here the great advantage of local EDS measurements to limit at the best the contribution of neighbouring phases. The high As/Co ratio measured on the blue section is in agreement with the use of European arsenic-rich cobalt ore [25]. Gold ( 48 wt\%) with silver traces $(\sim 6 \mathrm{wt} \%)$ is also detected in the red area, indicating coloration with $\mathrm{Au}^{\circ}$ nanoparticles, in other words the Cassius' purple. The very rough surface of the glaze demonstrates that the technology was not optimised, in agreement with an innovative production. The detection of pyrochlore traces by Raman 
microspectroscopy (Fig. 6a) arises from the pollution of the red areas close to the green one, due to the high fusibility and volatility of lead-reach glazes. The $1090 \mathrm{~cm}^{-1}$ peak indicates unreacted carbonate grains.

Green areas composition shows a rather low level of copper. This indicates that the green colour is not due to the presence of copper ions but results from the dispersion of pyrochlore pigment in a blue glass matrix, as for the Famille verte sample, the typical technology of the $18^{\text {th }}$ century European porcelains $[11,45]$. Confirmation is given by the recording of the Raman pyrochlore signature (Fig. 6). This demonstrates that Raman microspectroscopy is more efficient than elemental composition to identify a variety of colouring agents.

All overglaze spectra exhibit a significant $\mathrm{Pb}$ peak at ca. $2.4 \mathrm{keV}$, even for section analysis (Fig.7-6), which indicates diffusion of lead in all the glaze section (Fig. 2e \& f). Superimposition of lead and arsenic peaks takes place, maximising the intensity of the ca. $10.5 \mathrm{keV}$ peak. Comparison with data recorded in area free of arsenic and ZAF calculation should be considered as well as the Raman signatures. The EDS spectrum of the blue areas shows the characteristic Fe-Co doublet also observed for the Famille verte sample. Arsenic is detected in section analysis (Figs 7-6) at low level (0.4 wt \% $\mathrm{As}_{2} \mathrm{O}_{5}$ ). Since the blue overglaze has been made over or mixed with the white enamel, a high level of arsenic ( $3 \mathrm{wt} \% \mathrm{As}_{2} \mathrm{O}_{5}$, Table 1a) is measured. However arsenic-free cobalt-containing phase(s) is(are) detected in many spots such as shown on Fig. 7-2. Zinc seems to be also present (Table 1a). Copper, nickel and zinc traces are detected in green enamel but significant levels are measured in black lines in agreement with the spinel signature obtained by Raman scattering. A clear arsenic signal is measured in the white-blue mixture (Fig. 7-6).

\section{Qianlong fencai enamels}

Fig. 8 shows representative spectra collected on different coloured areas. This sample shows nice opaque painted enamels. The corresponding EDS spectra are shown in Fig. 9. All Raman spectra recorded on the enamel from the top surface show peak ranging from ca. 930 to $990 \mathrm{~cm}^{-1}$, characteristic of depolymerised lead-rich silicate [44] in agreement with the detection of up to $30 \mathrm{wt} \%$ $\mathrm{Pb}$ by EDS (Table 1b). Only the spectrum recorded close to the body-glaze interface (Fig. 9b3) appears lead-free ( $\sim \mathrm{wt} \%$, close to the limit of detection).

The red colour is obtained with hematite $\left(\alpha \mathrm{Fe}_{2} \mathrm{O}_{3}\right)$. The variation of the broadness and wavenumbers of the $215 / 230$ and $280 / 295 \mathrm{~cm}^{-1}$ doublet are consistent with the use of heterogeneous natural hematite in which a partial substitution of $\mathrm{Fe}$ atoms with $\mathrm{Ti}$ or $\mathrm{Al}$ takes place resulting in peak broadening [46]. The black line spectrum reveals the presence of a spinel structure (strong ca. 635-650 $\mathrm{cm}^{-1}$ ) peak $[46,47]$. The spectra recorded on yellow areas in different spots shows the $\left(\mathrm{Pb}_{2}[\mathrm{Sb} / \mathrm{Sn} / \mathrm{Fe} / \mathrm{Zn}]_{2} \mathrm{O}_{7-\delta}\right)$ complex pyrochlore Raman signature with its characteristic strong and narrow ca. 135 to $140 \mathrm{~cm}^{-1}$ peak $\left(\mathrm{T}^{\prime} \mathrm{Pb}^{2+}\right.$ ion mode, see above). Intense peaks (e.g. Fig. $8 \mathrm{~b}$ ) are recorded when the laser beam meets a large, well crystallized grain (> a few microns). The intensity of the ca. $440-450 \mathrm{~cm}^{-1}$ peak is 
consistent with a Sn-based pyrochlore in accordance with the detection of a Sn peak in some EDS spectra (Fig. 9 and Table 1b). Weaker signals are observed when the glaze matrix is dominant (Fig. 8a). The observation of a peak at ca. $90 \mathrm{~cm}^{-1}$ indicates a saturation of the enamel with $\mathrm{PbO}$, consistent with the strong band at $\sim 930 \mathrm{~cm}^{-1}$, characteristic of a Pb-rich silicate glass [44].

A ca. $820 \mathrm{~cm}^{-1}$ peak characteristic of lead-based arsenate (see above) is obtained for the blue enamel. However, examination of the enamel by optical microscopy (Fig. 3b and d) clearly shows that the blue enamel covers a white one deposited over the porcelain glaze. The EDS spectrum collected on a raster area of a few tens $\mu \mathrm{m}^{2}$ shows that the blue coloured area of the studied artefact can be free of As (Fig. 9a, Table 1b): in some spots the cobalt, iron and manganese contents are relatively high $\left(\mathrm{MnO}_{2}: 2.24\right.$ wt \%; $\mathrm{CoO}: 0.49 \mathrm{wt} \% ; \mathrm{Fe}_{2} \mathrm{O}_{3}: 2.22 \mathrm{wt} \%$ ), as usually observed for Ming and contemporary Vietnamese porcelains decorated with Asian cobalt ores [16,17,18,25,26,61]. Copper can be also present. The relatively high level of arsenic white makes difficult to assign the cobalt origin, Europe or Asia. The Raman spectrum of the white area (Fig. 8b) shows only the lead arsenate signature in agreement with its EDS spectrum (Fig. 9a \& 9b). Traces of iron are detected. EDS spectra recorded on a large blue area also detect arsenic, in agreement with the colour heterogeneity observed by optical microscopy (Fig. 3b). The green colour is obtained by dispersing $\mathrm{Cu}^{2+}$ ion (CuO: $\left.1.1 \mathrm{wt} \%\right)$ in the lead-based glass in agreement with the high level of $\mathrm{PbO}$ and $\mathrm{CuO}$ measured by EDS (Table 1b). Nickel is simultaneously detected (Fig. 9c). Observation of the pyrochlore pigment spectrum, in combination with the $818 \mathrm{~cm}^{-1}$ peak, characteristic of lead arsenate (Fig. 8a), proves that the small amount of cobalt ions ( $\mathrm{CoO}: 0.23 \mathrm{wt} \%$ ) also contributes to the green colour, in agreement with the detection of $\mathrm{Mn}, \mathrm{Fe}$, $\mathrm{Co}$ and $\mathrm{Cu}$ EDS peaks in green areas (Fig. 9a). The difference measured for blue and green spots (Fig. $9 \mathrm{c})$ proves that a specific copper-based compound was added or was part of the blue pigment.

Consistently with the characteristic $\mathrm{PO}_{4}$ stretching peak observed at ca. $950 \mathrm{~cm}^{-1}$ in some spots, especially of black areas (Fig. 8) phosphor is detected by EDS at high level for surface measurements (up to $15 \%$ wt, Table 1 ).

\subsection{Analysis with mobile Raman set-up}

Figs 10 and 11 compare representative spectra recorded with 532 and $785 \mathrm{~nm}$ laser excitations. As expected, the green excitation is more efficient than the red one for the study of glass and ceramic objects. From our experience the most appropriate colours are blue ones, $457 \mathrm{~nm}$ as used here at the laboratory or even better 407 or $413 \mathrm{~nm}[11,39]$.But to date no convenient mobile set-ups with blue laser excitation is available with convenient characteristics. Spectra rather similar or even better than those recorded with HR800 are obtained with $532 \mathrm{~nm}$ excitation in combination with the x200 ULWD Mitutoho objective. Furthermore a new spectrum is detected for the Famille rose shard. This new spectrum (773 and $950 \mathrm{~cm}^{-1}$ peaks with an overtone at $1485 \mathrm{~cm}^{-1}$ characteristics of the Sn-O bond perturbed with neighbouring chromium ions) recorded on red areas is characteristic of the pink malayite garnet, a 20th century pigment [62] in which the colour arises from a small addition of 
chromium to the calcium tin silicate. However, this phase forms naturally in glassy silicate when tin and chromium are both present, as observed for some Asian glass beads $[63,64]$. Tin and chromium are actually detected by EDS (Table 1a) with the expected ratio.

The strong background due to the Edge filter makes it difficult to observe broad bands in low intensity spectra, especially in the $300-500 \mathrm{~cm}^{-1}$ range where the background shape changes from a monotone increase to a rather flat behaviour; on the contrary narrow peaks are easily detected above $\sim 80 \mathrm{~cm}^{-1}$. A special procedure of baseline subtraction has been previously established [65] that guaranties a reliable comparison of data whatever the used instrument. In particular hematite, yellow pyrochlore and arsenate phases are well detected under green excitation. Consequently, the on-site study with $532 \mathrm{~nm}$ excitation gives a very representative set of Raman signatures, as recorded with sophisticated fixed Raman instrument. The huge sensitivity of the HE spectrometer in combination with the possibility to have up to $30 \mathrm{~mW}$ at the sample in a small volume (x200 ULWD objective) facilitates the detection of many phases. The power of illumination should be adapted to the colour of the studied area to avoid any heating and phase transition/oxidation.

\section{Discussion}

The presence of arsenic in blue decorated glaze of Chinese porcelains from the $18^{\text {th }}$ century was first evidenced by Zhang and Kingery \& Vandiver in 1985 [66,67] and confirmed more recently by elemental [23] and Raman analysis [14,21]. Similar Raman signatures were recorded in many European blue-decorated soft paste porcelains (but not always assigned to arsenate) [11-14] as well as in Limoges enamels [24], trade glass beads [35,64] and Chinese cloisonnés [24,52]. This is characteristic of the use of arsenic-rich European cobalt ores. Cobalt ores used during the Ming Dynasty are arsenic-poor but manganese and iron-rich [15,16,19,20,21,22,29,66-69]. Table 2 summarizes the results. Different types of cobalt ores have been evidenced: an 'arsenic-free' but ironrich cobalt in the Famille verte and Famille rose samples and a manganese-rich cobalt in the painted enamelled (Qianlong) sample, rather similar to the Mn-rich Asian cobalt ore(s) used since Yuan/Ming Dynasties [1,61,66-69] and in contemporary Vietnamese productions [16,17]. Arsenate is identified by EDS in the areas where As-O stretching band are recorded. From spot to spot heterogeneity is detected (e.g. As-rich or not) and it is not clear if different or heterogeneous cobalt ores have been used or if different mixing have been made. The use of different 'cobalt' precursors at the same time but by different workshops has been demonstrated for $17^{\text {th }}-18^{\text {th }}$ centuries Limoges enamels and it seems that the practice varies as a function of the workshop concerned [24]. Giannini et al. [23] recently analysed by LA-ICP-MS series of Famille rose shards; they observed a huge variation of the Mn to Co ratio depending on the sample: the $\mathrm{Mn}$ level varies from approximately $1000 \mathrm{ppm}$ to $50000 \mathrm{ppm}(\mathrm{Mn} / \mathrm{Co}=$ 5). Note that LA-ICP-MS measurements average the data but this is in agreement with the high heterogeneity measured by EDS in our samples. Pure cobalt ore will give a nice blue colour whatever the firing atmosphere. The use of Mn- or Fe-rich cobalt ores also lead to a nice blue colour but only if 
the firing takes place under reducing atmosphere: contribution of $\mathrm{Mn}$ and $\mathrm{Fe}$ ions to the colouration is thus negligible. Otherwise in oxidizing atmosphere the colour will be greenish or even black, as observed for some Vietnamese 'blue-and-white' porcelain because Vietnamese potters used a blue overglaze decor $[17,18]$, very sensitive to changes in the oxidising conditions at the end of the firing cycle. The blue underglaze decor is protected from the upper glaze layer. Note that a lead-rich overglaze requires firing under oxidizing atmosphere in order to avoid some blackening or loss of gloss (surface reduction to metal or formation of sulphides). The observation of similar arsenate Raman signatures in many (soft-paste) porcelains from French Factories (Chantilly, Mennecy, Sèvres, Sceaux)[5,11] as well as for European ones (Medici, Rockingham, Capo di Monte) $[12,13,70]$ is consistent with the use of European Arsenic-rich cobalt ores as those mined from Erzgebirge (Saxony) as proposed for $17^{\text {th }}$ and $18^{\text {th }}$ centuries Limoges enamels [24].

\section{Conclusion}

Combined Raman and EDS analysis probing the artefacts at a similar probe scale gives very consistent results. Mobile Raman microspectroscopy alone appears also very efficient to identify all the phases of the ceramic wares. Spectra recorded with the HE532 Raman set-up equipped with a x200 ULWD microscope objective are generally of better quality than those recorded at the laboratory with advanced instruments, except the more complex background and the impossibility to record Raman scattering below $80 \mathrm{~cm}^{-1}$. Measurements with a x200 ultra long working distance require the test of many spots to get a representative view; therefore, combination with a $x 50$ ULWD objective is recommended. Chemical elements involved in phases identified by Raman microspectroscopy are confirmed by EDS. Previous works have demonstrated that Raman mapping is more efficient than Xray diffraction to identify all the minor phases present in a pottery [71]. In particular, because of the huge Raman cross section of the As-O bond, arsenate-based phases (opacifier or that was formed because the use of As-rich cobalt ores) are well detected. Specific chromophores such as pink malayite are also detected as second phases because of the resonance Raman condition. This rare signature could be an interesting marker of historic and geographic productions. On these aspects, the EDS analysis confirms all Raman identifications. Both techniques demonstrate the local heterogeneity of the enamels and further comprehensive studies of this heterogeneity (e.g. mapping and in-depth profiling) could be used to compare production technologies, e.g. between provincial and imperial kiln productions. The high sensitivity and rapidity of data collection of non-invasive mobile Raman spectroscopy is of great advantage to study series of rare and precious historic items for a more representative and systemic study of the variety of technologies used for the world's most brilliant colour enamelling at the turn of $17^{\text {th }}-18^{\text {th }}$ centuries in and outside of China. 


\section{References}

1. N. Wood, Chinese Glaze: Their Origins, Chemistry, and Recreation, University of Pennsylvania Press, Philadelphia, 1999.

2. J. Geyssant, Secret du verre rouge transparent de Bernard Perrot et comparaison avec celui de Johann Kunckel, Somogy-Editions d'Art, Paris, 2010, p.51-54

3. P. Ricciardi, Ph. Colomban, A. Tournié, V. Milande, Non-destructive on-site identification of ancient glasses: genuine artefacts, embellished pieces or forgeries?, J. Raman Spectrosc. 40 (2009) 604-617.

4. A. Bouthier, Bernard Perrot entre secret et innovations, Les Innovations Verrières et leur Devenir, Actes du 2è Colloque Verre et Histoire, Nancy, 26-28 mars 2009, http://www.verrehistoire.org/colloques/innovations/pages/p205_01_bouthier.html (access 18th May 2017).

5. D. Mancini, C. Dupont-Logié, Ph. Colomban, On-site identification of Sceaux porcelain and faience using a portable Raman instrument, Ceram. Int. 42[13] (2016) 14918-14927.

6. E.B. Curtis, European contributions to the Chinese glass of the early Qing period, J. Glass Stud. 35 (1993) 91-101.

7. E.B. Curtis, Glass exchange between Europe and China, 1550-1800: Diplomatic, Mercantile and Technological Interactions, Ashgate, Farnham, 2009, UK.

8. F. Lili, La céramique chinoise, China Intercontinental Press, Beijing, 2011.

9. B. Zhao, G. Wang, I. Biron, Ph. Colomban, L. Hilaire-Pérez, La circulation des techniques de l'émail entre la France et la Chine du XVIIème au XIXème siècle, Le Cnrs en Chine Bulletin 21

http://www.cnrs.fr/derci/IMG/pdf/cnrsenchine_21_fr_final_pour_le_site_cnrs.pdf

10. X.D. Xu, Europe-China-Europe: The Transmission of the Craft of Painted Enamel in the Seventeenth and Eighteenth Centuries, Goods from the East, 1600-1800 Trading Eurasia, Maxine Berg ed. , Houndmills, Basingstoke, Hampshire: Palgrave Macmillan, 2015, pp. $92-$ 106.

11. Ph. Colomban, I. Robert, C. Roche, G. Sagon, V. Milande, Identification des porcelaines "tendres" du $18^{\text {ème }}$ siècle par spectroscopie Raman: Saint-Cloud, Chantilly, Mennecy et Vincennes/Sèvres, Revue d'Archéométrie 28 (2004) 153-167.

12. Ph. Colomban, V. Milande, H. Lucas, On-site Raman Analysis of Medici Porcelain, J. Raman Spectrosc. 35 [1] (2004) 68-72.

13. P. Ricciardi, Ph. Colomban, V. Milande, Non-destructive Raman characterization of Capodimonte and Buen Retiro porcelain, J. Raman Spectrosc. 39 (2008) 1113-1119. 
14. Ph. Colomban, Y. Zhang, B. Zhao, Non-invasive Raman analyses of huafalang and related porcelain wares. Searching for evidence for innovative pigment technologies, doi:10.1016/j.ceramint.2017.06.063 .

15. K.N. Yu, J.M. Miao, Locating the origin of blue and white porcelains using EDXRF, Appl. Radiat. Isot. 48 (1997) 959-963.

16. A. Morimoto, K. Yamasaki, K. (eds.), 2001, Technical studies on ancient ceramics found in north and central Vietnam, Fukuoka Museum, Fukuoka.

17. N.Q. Liem, Ph. Colomban, G. Sagon, H.X. Tinh, T.B. Hoanh, Microstructure, Composition and Processing of the $15^{\text {th }}$ century Vietnamese Porcelains and Celadons, J. Cult. Herit. 4[3] (2003) 187-197.

18. Ph. Colomban, G. Sagon, L.Q. Huy, N.Q. Liem, L. Mazerolles, Vietnamese ( $15^{\text {th }}$ century) blue-and-white, tam thai and "luster" porcelains/stoneware: glaze composition and decoration techniques, Archaeometry 46[1] (2004) 125-136.

19. M.O. Figueiredo, T.P. Silva, J.P. Veiga, A XANES study of cobalt speciation state in blueand-white glazes from $16^{\text {th }}$ to $17^{\text {th }}$ century Chinese porcelains, J. Electr. Spectrosc. \& Rel. Phenom. 185 (2012) 97-102.

20. M.I. Dias, M.I. Prudêncio, M.A. Pinto de Matos, A.L. Rodrigues, Tracing the origin of blue and white Chinese Porcelain ordered for the Portugese market during the Ming dynasty using INAA, J. Archaeolog. Sci. 40 (2013) 3046-3057.

21. J. Van Pevenage, D. Lauwers, D. Herremans, E. Verhaeven,B. Vekemans, W. De Clercq, L. Vincze, L. Moens, P. Vandenabeele, A Combined Spectroscopic Study on Chinese Porcelain Containing Ruan-Cai Colours, Anal. Methods 6 (2014) 387-394.

22. T. Zhu, X. Ding, C.M. Kusimba, Z. Feng, Using laser ablation inductively coupled plasma mass spectroscopy (LA-ICP-MS) to determine the provenance of the cobalt pigment of qinghua porcelain from Jingdezhen in Yuan Dynasty of China (1271-1368 AD), Ceram. Int. 41 (2015) 9878-9884.

23. R. Giannini, I.C. Freestone, A.J. Shortland, European Cobalt Sources Identification in the Production of Chinese Famille Rose Porcelain, J. Archaeolog. Sci. 80 (2017) 27-36.

24. Ph. Colomban, L. Arberet, B. Kirmizi, On-site analysis of $17^{\text {th }}-18^{\text {th }}$ centuries Limoges enamels. Arsenic and the technological relationship between enamelled Limoges and Chinese wares, Ceram. Int. 43 (2017) 10158-10165.

25. Ph. Colomban, Rocks as blue (green and black) pigments/dyes of glazed pottery and enamelled glass artefacts - The potential of Raman microscopy, Eur. Mineral. J. 25 [5] (2013) 863-879.

26. M.C. Caggiani, C. Valloteau, Ph. Colomban, Inside the glassmaker technology: Search of Raman criteria to discriminate between Emile Gallé and Philippe-Joseph Brocard Enamels and Pigment Signatures, J. Raman Spectrosc. 45[6] (2014) 456-464. 
27. G. Simsek, Ph. Colomban, F. Casadio,'L. Bellot-Gurlet, K. Faber, G. Zelleke, V. Milande, L. Tilliard, On-site identification of early Böttger red stonewares using portable XRF/Raman instruments: 2, glaze and gilding analysis, J. Am. Ceram. Soc. 98 [10] (2015) 3006-3013.

28. $\mathrm{Ph}$. Colomban, The on-site/remote Raman analysis with portable instruments - A review of drawbacks and success in Cultural Heritage studies and other associated fields, J. Raman Spectrosc. 43 [11] (2012) 1529-1535.

29. C. Fischer, E. Hsieh, Export Chinese Blue-and-White Porcelain: Compositional Analysis and Sourcing Using Non-Invasive Portable XRF and Reflectance Spectroscopy, J. Archaeolog. Sci. 80 (2016) 14-26.

30. Ph. Colomban, Lapis Lajuli as unexpected blue pigment in Lâjvardina ceramics, J. Raman Spectrosc. 34 [6] (2003) 420-423.

31. Ph. Colomban, A. Tournié, M.-C. Caggiani, C. Paris, Pigments and enamelling/gilding technology of Mamluk mosque lamps and bottle, J. Raman Spectrosc. 43[12] (2012) 19751984.

32. R.A. Epler, D.R. Epler, Glazes and Glass Coating, The American Ceramic Society, Westerville, 2000.

33. B. Gratuze, I. Soulier, M. Blet, L. Vallauri, De l'origine du cobalt: du verre à la céramique', Revue d'Archéométrie 20 (1996) 77-104.

34. F. Koleini, I. Pikirayi, Ph. Colomban, Revisiting Baranda: a multi-analytical approach in the classification of sixteenth/seventeenth century glass beads from northern Zimbabwe, Antiquity 91 [357] (2017) 751-765.

35. R.G.V. Hancock, J. McKechnie, S. Aufreiter, K. Karklins, M. Kapches, M. Sempowski, J.F. Moreau, I. Kenyon, Non-destructive analysis of European cobalt blue glass trade beads, J. Radioanal. \& Nucl. Chem. 244[3] (2000) 567-573.

36. E. Neri, C. Morvan, Ph. Colomban, M. P. Guerra, V. Prigent, Late Roman and Byzantine Mosaic opaque "Glass-ceramics" Tesserae $\left(5^{\text {th }}-9^{\text {th }}\right.$ century), Ceram. Int. 42 [16] (2016) 18859-18869.

37. Ph. Colomban, Structure of oxide gels and glasses by infrared and Raman scattering: Part 2, Mullite, J. Mater. Sci. 24 (1989) 3011-320.

38. D. Michel, Ph. Colomban, S. Abolhassani, F. Voyron, A. Kahn-Harari, Germanium mullite: structure and vibrational spectra of gels, glasses and ceramics, J. Eur. Ceram. Soc. 16 (1996) 161-168.

39. Ph. Colomban, F. Treppoz, Identification and Differentiation of Ancient and Modern European Porcelains by Raman Macro- and Microspectroscopy, J. Raman Spectrosc. 32 (2001) 93-102. 
40. Ph. Sciau, L. Noe, Ph. Colomban, Metal nanoparticles in contemporary potters' master pieces: Lustre and red "pigeon blood" pottery: Models to understand the ancient technology, Ceram. Int. 42 (2016) 15349-15357.

41. N.Q. Liem, G. Sagon, V.X. Quang, H.V. Tan, Ph. Colomban, Raman structure of the microstructure, composition and processing of ancient Vietnamese (pro)porcelains and celadons (13 ${ }^{\text {th }}-16^{\text {th }}$ centuries), J. Raman Spectrosc. 31 (2000) 933-942.

42. Ph. Colomban, E. Bruneton, J.L. Lagrange, E. Mouchon, Sol-Gel mullite matrix-SiC and mullite 2D woven fabric composites with or without zirconia containing interphase:

Elaboration and Properties, J. Eur. Ceram. Soc. 16 (1996) 301-314.

43. C.A., Jouenne, Céramique Générale -Notions de Pysico-Chimie, (2 tomes), Gauthier-Villard, Paris, 1960.

44. Ph. Colomban, A. Tournié, L. Bellot-Gurlet, Raman Identification of glassy silicates used in ceramic, glass and jewellry: a tentative differentiation guide, J. Raman Spectrosc. 37 [8] (2006) 841-852.

45. Ph. Colomban, G. Sagon, X. Faurel, Differentiation of antique ceramics from the Raman spectra of their coloured glazes and paintings, J. Raman Spectrosc. 32[5] (2001) 351-360.

46. F. Froment, A. Tournié, Ph. Colomban, Raman identification of natural red to yellow pigments: ochre and iron-containing ores, J. Raman Spectrosc. 39[5] (2008) 560-568.

47. Z. Cvejic, S. Rakic, A. Kremenovic, B. Antic, C. Jovalekic, Ph. Colomban, Nanosize ferrites obtained by ball milling. Crystal structure, cation distribution, size-strain analysis and Raman investigations, Solid State Science 8 (2006) 908-915.

48. Ph. Colomban, G. Sagon, L.Q. Huy, N.Q. Liem, L. Mazerolles, Vietnamese (15 ${ }^{\text {th }}$ century) blue-and-white, tam thai and "luster" porcelains/stoneware: glaze composition and decoration techniques, Archaeometry 46 [1] (2004) 125-136.

49. A. Culka, H. Kindlova, P. Drahota, J. Jehlicka, Raman spectroscopic indentification of arsenate minerals in situ at outcrops with handled $(532 \mathrm{~nm}, 785 \mathrm{~nm})$ instruments, Spectrochimica Acta Part A 154 (2016) 193-199.

50. B. Manoun, M. Azdouz, M. Azrour, R. Essehli, S. Benmokhtar, L. El Ammari, A. Ezzahi, A.Ider, P. Lazor, Synthesis, Rietveld Refinements and Raman Spectroscopic Studies of Tricationic Lacunar Apatites $\mathrm{Na}_{1-\mathrm{x}} \mathrm{K}_{\mathrm{x}} \mathrm{Pb}_{4}\left(\mathrm{AsO}_{4}\right)_{3}(0<\mathrm{x}<1)$, J. Mol. Struct. 986 (2011) 1-9.

51. T. Mouri, M. Enami, Raman spectroscopic study of olivine-group mineral, J. Mineralog. \& Petrolog. Sci., 103 (2008) 100-104.

52. B. Kirmizi, Ph. Colomban, M. Blanc, On-site Analysis of Limoges enamels from $16^{\text {th }}$ to $19^{\text {th }}$ centuries, J. Raman Spectrosc. 41 [10] (2010) 1240-1247.

53. M. Pereira, T. de Lacerda-Aroso, M.J.M. Gomes, A. Mata, L.C. Alves, Ph. Colomban, Ancient Portuguese Ceramic Wall Tiles («Ajulejos »): Characterization of the Glaze and Ceramic Pigments, J. Nano Research 8 (2009) 79-88. 
54. C. Sandalinas, S. Ruiz-Moreno, Lead-tin-antimony yellow. Historical manufacture molecular characterization and identification in seventeenth-century Italian paintings, Stud. Conserv. 40 (2004) 41-53.

55. C. Sandalinas, S. Ruiz-Moreno, A. Lopez-Gil, J. Miralles, Experimental confirmation by Raman spectroscopy of a $\mathrm{Pb}$-Sn-Sb triple oxide yellow pigment in sixteenth-century Italian pottery, J. Raman Spectrosc. 37 (2006) 1146-1153.

56. F. Rosi, V. Manualli, C. Milliani, B.G. Brunetti, A. Sgamellotti, T. Grygar, D. Hradil, Raman scattering features of lead pyroantimonate compounds. Part I: XRD and Raman characterization of $\mathrm{Pb}_{2} \mathrm{Sb}_{2} \mathrm{O}_{7}$ doped with tin and zinc, J. Raman Spectrosc. 40 (2009) 107111.

57. C. Pelosi, G. Agresti, U. Santamaria, E. Mattei, Artifical yellow pigments: Production and characterization through spectroscopic methods of analysis, ePreservationScience 7 (2010) 108-115.

58. B. Kirmizi, H. Gokturk, Ph. Colomban, Colouring Agents in the Pottery Glazes of Western Anatolia: A New Evidence for the Use of Naples Yellow Pigment Variations during the Late Byzantine Period, Archaeometry 57 [3] (2015) 476-496.

59. A. Steele, M.D. Fries, H.E.F. Amundsen, B.O. Mysen, M.L. Fogel, M. Schweizer, N.Z. Boctor, Comprehensive imaging and Raman spectroscopy of carbonate globules from Martian meteorite ALH 84001 and a terrestrial analogue from Svalbard, Meteoritics \& Planetary Science, 42 (2007)1549-1566.

60. Ph. Colomban, Th. Calligaro, Cl. Vibert-Guigue, N. Q. Liem, H.G.M. Edwards, Accrochage des dorures sur les céramiques et tesselles anciennes, ArcheoSciences-Revue d'Archéométrie 29 (2006) 7-20.

61. T.Q. Zhu, X. Ding, C.M. Kusimba, Z.Y. Feng, Using laser ablation inductively coupled plasma mass spectroscopy (LA-ICP-MS) to determine the provenance of the cobalt pigment of Qinghua porcelain from Jingdezhen in Yuan Dynasty of China (1271-1368AD), Ceram. Int. 41[8] (2015) 9878-9884.

62. X. Faurel, A. Vanderperre, Ph. Colomban, Pink optimization by Resonance Raman Spectroscopy, J. Raman Spectrosc. 34 (2003) 290-294.

63. N. Fischbach, A.-T. Ngo, Ph. Colomban, M. Pauly, Beads excavated from Antsiraka Boira necropolis (Mayotte Island, $12^{\text {th }}-13^{\text {th }}$ centuries). Colouring agents and glass matrix composition -Comparison with contemporary Southern African sites, ArcheoSciences-Revue d'Archéométrie 24 (2016) 83-102.

64. F. Koleini, L. C. Prinsloo, W. Biemond, Ph. Colomban, A.-T. ngo, J.C.A. Boeyens, M.M. Van der Ryst, K. van Brakel, Unravelling the glass trade bead sequence from Magoro hill, South Africa: separating pre-seventeenth-century Asian imports from later European counterparts, Heritage Science 4 (2016) 43 http://dx.doi.org/10.1186/s40494-016-0113-2 
65. Ph. Colomban, On-site Raman identification and dating of ancient glasses: procedures and tools, J. Cult. Herit. 9 Suppl. (2008) e55-e60.

66. F. Zhang, The origin and development of traditional Chinese glazes and decorative ceramic colors, in Ancient Technology to Modern Science, vol. 1, Ceramics and Civilizations Serie, W.D. Kingery, vol. 1, The American Ceramic Society, Colombus, 1985, p. 163-179.

67. W.D. Kingery, P.B. Vandiver, The eighteenth-century change in technology and style from the Famille-Verte palette to the Famille-Rose Palette, in Technology and Style, Vol. 2, Ceramics and Civilization Serie, W.D. Kingery Ed., The American Ceramic Society, Colombus, 1986, p. 363-381.

68. Y.A. Qu, J. Xie, X.Q. Xi, C.J. Huang, J.L. Yang, Microstructure characteristics of blue-andwhite porcelain from the folk kiln of Ming and Qing Dynasties, Ceram. Int. 40 [6] (2014) 8783-8790.

69. F. Du, B.R. Su, Further study of sources of the imported cobalt-blue pigment used on Jingdezhen porcelain from late 13 to early 15 centuries, Sci. China Series E - Techn. Sci. 51 [3] (2008) 249-259.

70. H.G.M. Edwards, Ph. Colomban, B. Bowden, Raman spectroscopic analysis of an English soft-paste porcelain plaque-mounted table, J. Raman Spectrosc. 35 (2004) 656-661.

71. B. Minceva-Sukarova, A. Issi, A. Raskovska, O. Grupce, V. Tanevska, M. Yaygingöl, A. Kara, $\mathrm{Ph}$. Colomban, Characterization of pottery from Republic of Macedonia. III A study of the comparative mineralogical efficiency using micro-Raman mapping and X-ray diffraction, J. Raman Spectrosc. 43 [6] (2012) 792-798. 


\section{Figure Captions}

Fig. 1: Famille verte shard, verso (a) and recto (b, "Great Qing Dynasty Kangxi Reign Creation" mark); in c) details of the mark visible under the porcelain glaze; d) section showing the diffusion of the blue colour in the body and the upper glaze; e) detail of the green enamel deposited over the glazed blue decoration; f) and g) sections of the blue glazed areas, note the thin red enamel close to g) label; $h$ ) details of red zone (bar $=500 \mu \mathrm{m}$, Photo Ph. Colomban).

Fig. 2: Famille rose shard (a) and details of the rim ( $\left.a^{\prime}\right)$; detail of the partially missing gilding and of the black line are shown in b) and c), respectively; upper view of the blue enamel (d) and of the sections of red (e) and (f) green areas (bar $=500 \mu \mathrm{m}$, Photo Ph. Colomban).

Fig. 3: Qianlong ware shard (a); details of the coloured areas are shown in b), c) and f); sections showing the blue enamel covering the glaze (d), the green glaze $(\mathrm{g})$ and the red enamel covering the glaze (g), (bar $=500 \mu \mathrm{m}$, Photo Ph. Colomban).

Fig. 4: Representative Raman (left) spectra of the different phases evidenced in the porcelain body and corresponding EDS spectra (right).

Fig. 5: Representative Raman spectra recorded on the different coloured areas of the Famille verte shard and corresponding EDS spectra : 1, blue area surface, close to the green area; 2, blue area section (Fig. 1d); 3, black line; 4, green area overglaze (Fig. 1e).

Fig. 6: Representative Raman spectra recorded on the different coloured areas of the Famille rose shard (surface analysis).

Fig. 7: Representative EDS spectra recorded on the different coloured areas of the Famille rose shard: 1 to 5 , surface analysis; 6 , section analysis (1, red area, $2 \& 4$, blue area; 3 \& 5, green area; 6 , blue and white area; comparison between gold and 'red' areas is given, see Table $1 a)$.

Fig. 8: Representative Raman spectra recorded on the different coloured areas of the Qianlong shard (a), surface analysis; b), section analysis).

Fig. 9: Representative EDS spectra recorded on the different coloured areas of the Qianlong hard (a), surface analysis; b), section analysis ( $1 \& 4$, blue are; 2 , green area; $c$ ), very local analysis).

Fig.10: Representative spectra recorded with mobile HE532 Raman set-up equipped with a x200 ULWD microscope objective: a) Famille verte; b) Famille rose; c) Qianlong ware.

Fig. 11: Representative spectra recorded with mobile HE785 Raman set-up equipped with a x40 IR optimised LWD microscope objective. 
Table 1a: Oxide (\%wt) composition of representative coloured enamels/glazes of Famille verte and Famille rose shards. Characteristic values are given in bold.

\begin{tabular}{|c|c|c|c|c|c|c|c|c|}
\hline & \multicolumn{3}{|c|}{ Famille verte (Fig. 5b) } & \multicolumn{5}{|c|}{ Famille rose (Fig. 7) } \\
\hline Oxide & blue2 & black3 & green4 & FR red & FR blue2 & FR green3 & FR blue-white6 & Gold \\
\hline & blue & black & green & Red & blue & green & Blue-white & Gold \\
\hline $\mathrm{SiO}_{2}$ & 68.39 & 63.41 & 54.18 & 30.59 & 65.08 & 78.46 & 53.37 & 3.70 \\
\hline $\mathrm{Al}_{2} \mathrm{O}_{3}$ & 19.18 & 20.81 & 26.71 & 9.65 & 17.83 & 13.34 & 17.47 & 0.95 \\
\hline $\mathrm{CaO}$ & 3.02 & 4.47 & 9.79 & 2.06 & 4.96 & 1.46 & 5.29 & 0.14 \\
\hline $\mathrm{MgO}$ & 0.68 & 0 & 2.1 & 0 & 1.68 & 2.07 & 1.11 & - \\
\hline $\mathrm{K}_{2} \mathrm{O}$ & 0.55 & 3.16 & 2.40 & 1.75 & 3.27 & 1.87 & 4.20 & - \\
\hline $\mathrm{Na}_{2} \mathrm{O}$ & 0.41 & 0.71 & 0.60 & - & 0.316 & 1.44 & 1.54 & - \\
\hline $\mathrm{Fe}_{2} \mathrm{O}_{3}$ & 4.41 & 1.21 & 1.59 & 2.51 & 4.26 & 0.17 & 4.16 & 0.90 \\
\hline $\mathrm{NiO}$ & 0.23 & 0.48 & 0.07 & - & 0.21 & 0.14 & 0.22 & - \\
\hline CuO & 0.25 & 0.35 & 0.08 & - & 0.32 & 0.09 & 0.33 & - \\
\hline $\mathrm{ZnO}$ & 0.21 & 0.42 & 0.17 & - & 0.15 & 0.03 & 0.33 & - \\
\hline PbO & 1.91 & 1.99 & 0.7 & - & 0.36 & 0.50 & 6.16 & - \\
\hline $\mathrm{MnO}_{2}$ & 0.05 & 0.84 & 0.06 & - & 0.11 & 0.03 & 0.30 & - \\
\hline $\mathrm{CoO}$ & 0.34 & 0.31 & 0.06 & - & 0.28 & 0.04 & 0.20 & - \\
\hline $\mathrm{SnO}_{2}$ & 0.37 & 1.82 & 1.53 & - & 1.65 & 0.36 & 2.28 & - \\
\hline $\mathrm{As}_{2} \mathrm{O}_{5}$ & $\sim 0$ & $\sim 0$ & $\sim 0$ & - & 0.41 & $\sim 0$ & 2.95 & - \\
\hline Ag & - & - & - & 5.76 & - & - & - & 2.44 \\
\hline $\mathrm{Au}$ & - & - & - & 47.67 & - & - & - & 92.28 \\
\hline $\mathrm{Cr}_{2} \mathrm{O}_{3}$ & - & - & - & - & 0.14 & 0.002 & 0.09 & - \\
\hline Total & 100 & 100 & 100 & 100 & 100 & 100 & 100 & 100 \\
\hline
\end{tabular}

- $\quad$ : not measured or below the detection limit. 
Table 1b: Oxide (\%wt) composition of representative 'doucai' coloured enamels/glazes. Characteristic values are given in bold.

\begin{tabular}{|c|c|c|c|c|c|c|c|c|c|}
\hline \multirow[t]{3}{*}{ Oxide } & \multicolumn{9}{|c|}{ 'Qianlong' ware } \\
\hline & \multicolumn{4}{|c|}{$\begin{array}{c}\text { Fig 9a } \\
\text { (surface) }\end{array}$} & \multicolumn{4}{|c|}{$\begin{array}{c}\text { Fig 9b } \\
\text { (section) }\end{array}$} & \multirow{2}{*}{$\begin{array}{c}\text { Fig 9c } \\
\text { (very local, } \\
\text { section) } \\
\text { blue }\end{array}$} \\
\hline & yellow & blue & white & glaze & blue1 & body & green2 & white & \\
\hline $\mathrm{SiO}_{2}$ & 54.16 & 30.19 & 51.64 & 64.76 & 40.24 & 71.04 & 38.33 & 26.77 & 12.78 \\
\hline $\mathrm{Al}_{2} \mathrm{O}_{3}$ & 9.02 & 20.54 & 7.88 & 17.71 & 30.44 & 21.55 & 32.97 & 8.11 & 34.138 \\
\hline $\mathrm{CaO}$ & 8.95 & 5.49 & 2.24 & 1.72 & 4.17 & 0.84 & 1.69 & 2.69 & 1.59 \\
\hline $\mathrm{MgO}$ & 1.85 & 1.00 & 1.55 & 0.01 & $\sim 0$ & $\sim 0$ & $\sim 0$ & 1.16 & $\sim 0$ \\
\hline $\mathrm{K}_{2} \mathrm{O}$ & 2.54 & 3.04 & 4.91 & 4.65 & 1.67 & 2.18 & 2.27 & 1.67 & 1.57 \\
\hline $\mathrm{Na}_{2} \mathrm{O}$ & 1.23 & 4.96 & 0.40 & 2.67 & 0.13 & 1.27 & 0 & 0.91 & 0 \\
\hline $\mathrm{Fe}_{2} \mathrm{O}_{3}$ & 2.11 & 3.12 & 1.01 & 1.22 & 2.22 & 0.46 & 0.99 & 0.92 & 8.57 \\
\hline $\mathrm{TiO}_{2}$ & - & - & - & - & - & - & - & - & 0.79 \\
\hline $\mathrm{P}_{2} \mathrm{O}_{5}$ & 13.89 & 14.50 & 1.20 & 0.65 & 2.27 & 0.10 & 0.18 & 1.65 & - \\
\hline $\mathrm{NiO}$ & 0.36 & 0.30 & 0.26 & 0.24 & 0.14 & 0.05 & 0.24 & 0.30 & 1.45 \\
\hline $\mathrm{CuO}$ & 0.46 & 0.45 & 0.29 & 0.27 & 0.86 & 0.15 & 1.10 & 0.70 & 1.46 \\
\hline Zno & 0.71 & 0.60 & 0.63 & 0.39 & 0.18 & 0.11 & 0.13 & 0.32 & 1.99 \\
\hline $\mathrm{PbO}$ & 3.17 & 5.81 & 11.75 & 4.36 & 9.71 & 1.02 & 12.91 & 30.19 & 17.99 \\
\hline $\mathrm{SnO}_{2}$ & 2.11 & 0.5 & 1.24 & 1.00 & 0.65 & 1.04 & 0.68 & 1.51 & 0.80 \\
\hline $\mathrm{As}_{2} \mathrm{O}_{5}$ & $\sim 0$ & $\sim 0$ & 14.32 & $\sim 0$ & 4.58 & $\sim 0$ & 7.95 & 22.58 & 15.19 \\
\hline $\mathrm{CoO}$ & 0.23 & 1.54 & 0.40 & 0.13 & 0.49 & 0.13 & 0.23 & 0.33 & 1.36 \\
\hline $\mathrm{MnO}_{2}$ & 0.22 & 6.43 & 0.38 & 0.22 & 2.24 & 0.06 & 0.26 & 0.20 & 0.31 \\
\hline Total & 100 & 100 & 100 & 100 & 100 & 100 & 100 & 100 & 100 \\
\hline
\end{tabular}

: not measured or below the detection limit. 


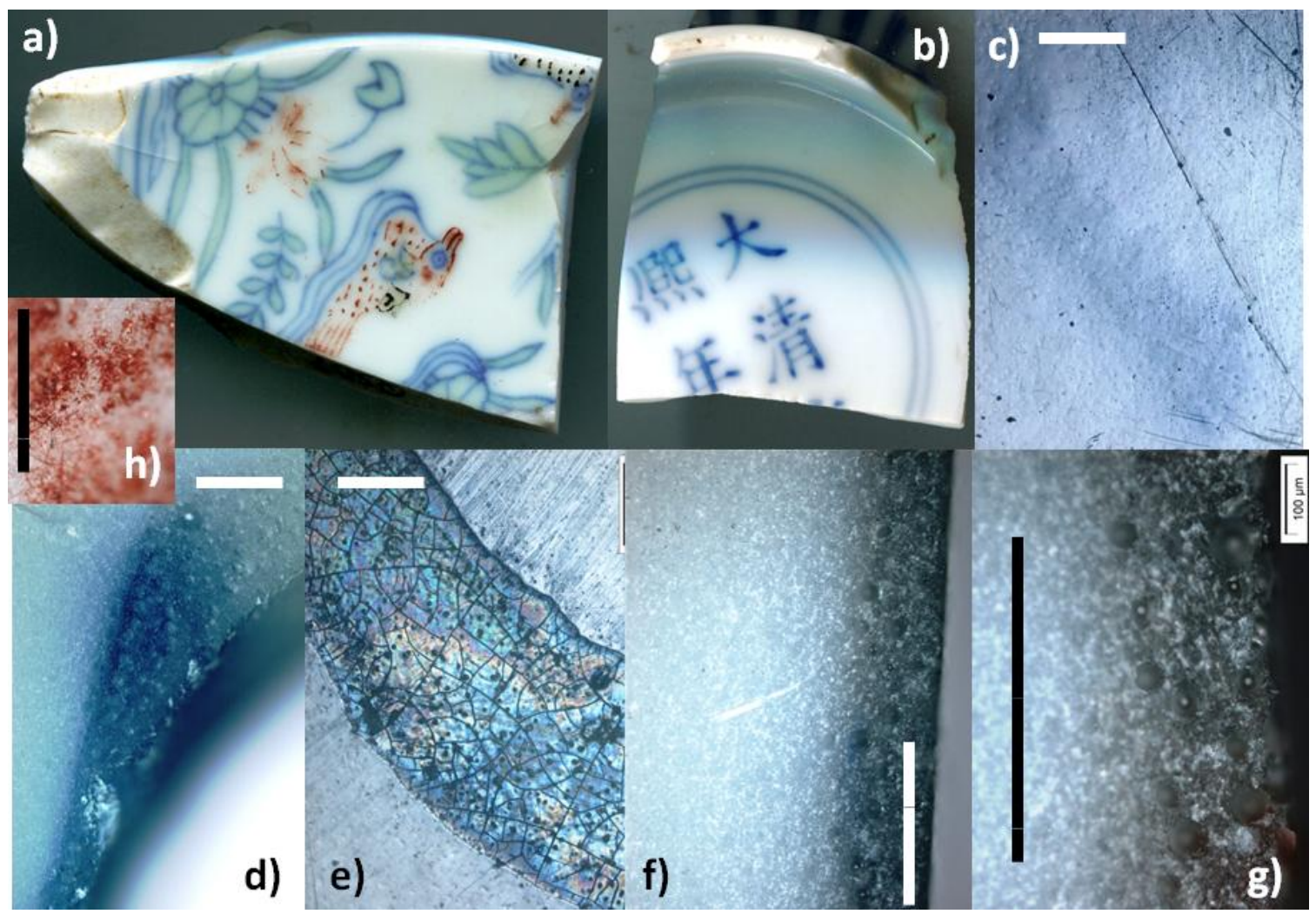

Fig. 1: Famille verte shard, verso (a) and recto (b, "Great Qing Dynasty Kangxi Reign Creation" mark); in c) details of the mark visible under the porcelain glaze; d) section showing the diffusion of the blue colour in the body and the upper glaze; e) detail of the green enamel deposited over the glazed blue decor; f) and g) sections of the blue glazed areas, note the thin red enamel close to g) label (bar = $500 \mu \mathrm{m}$, Photo Ph. Colomban). 


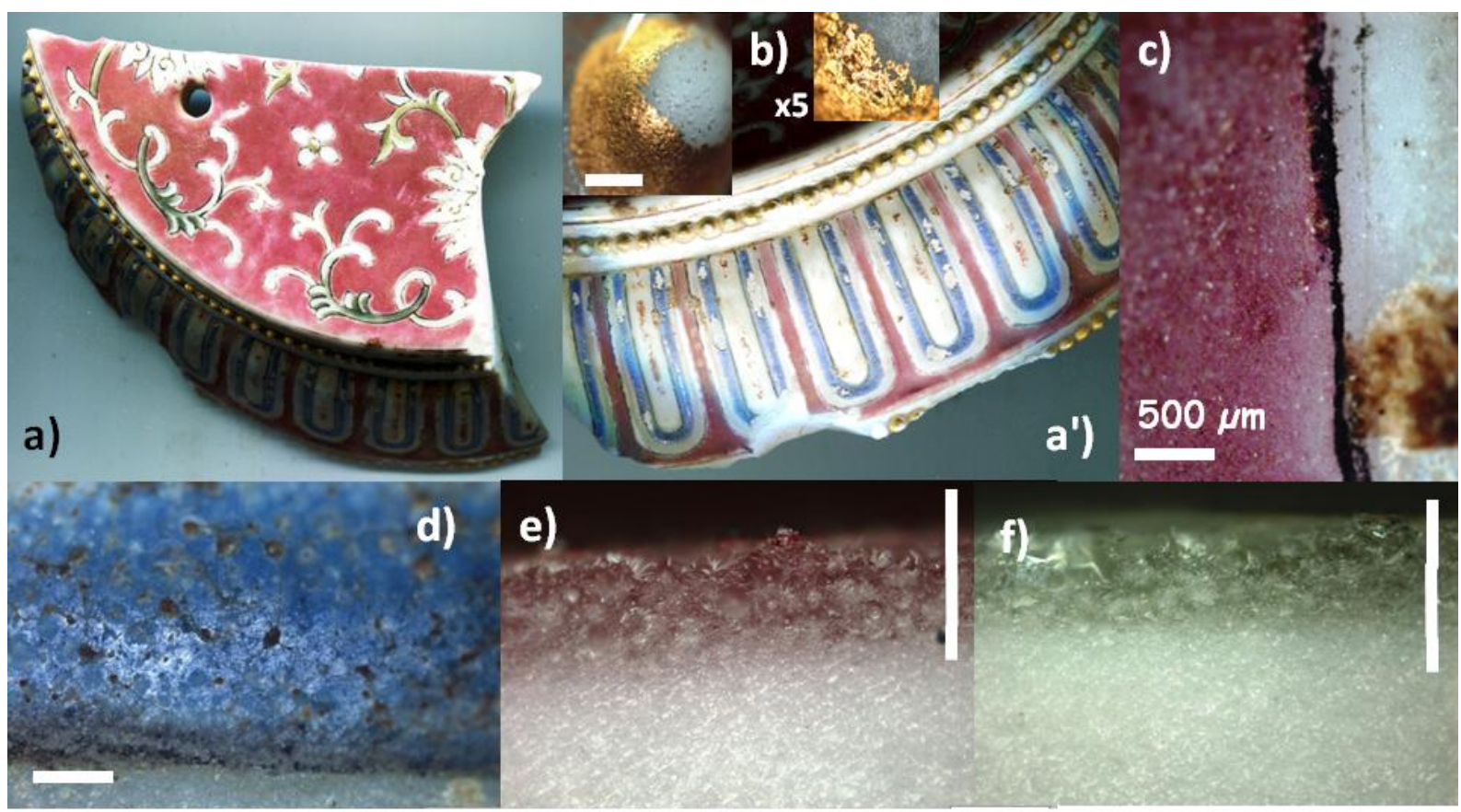

Fig. 2: Famille rose shard (a) and details of the rim (a'); detail on the partially missing gilding and of the black line are shown in b and c, respectively; upper view of the blue enamel (d) and of the sections of red (e) and (f) green areas (bar $=500 \mu \mathrm{m}$, Photo Ph. Colomban). 


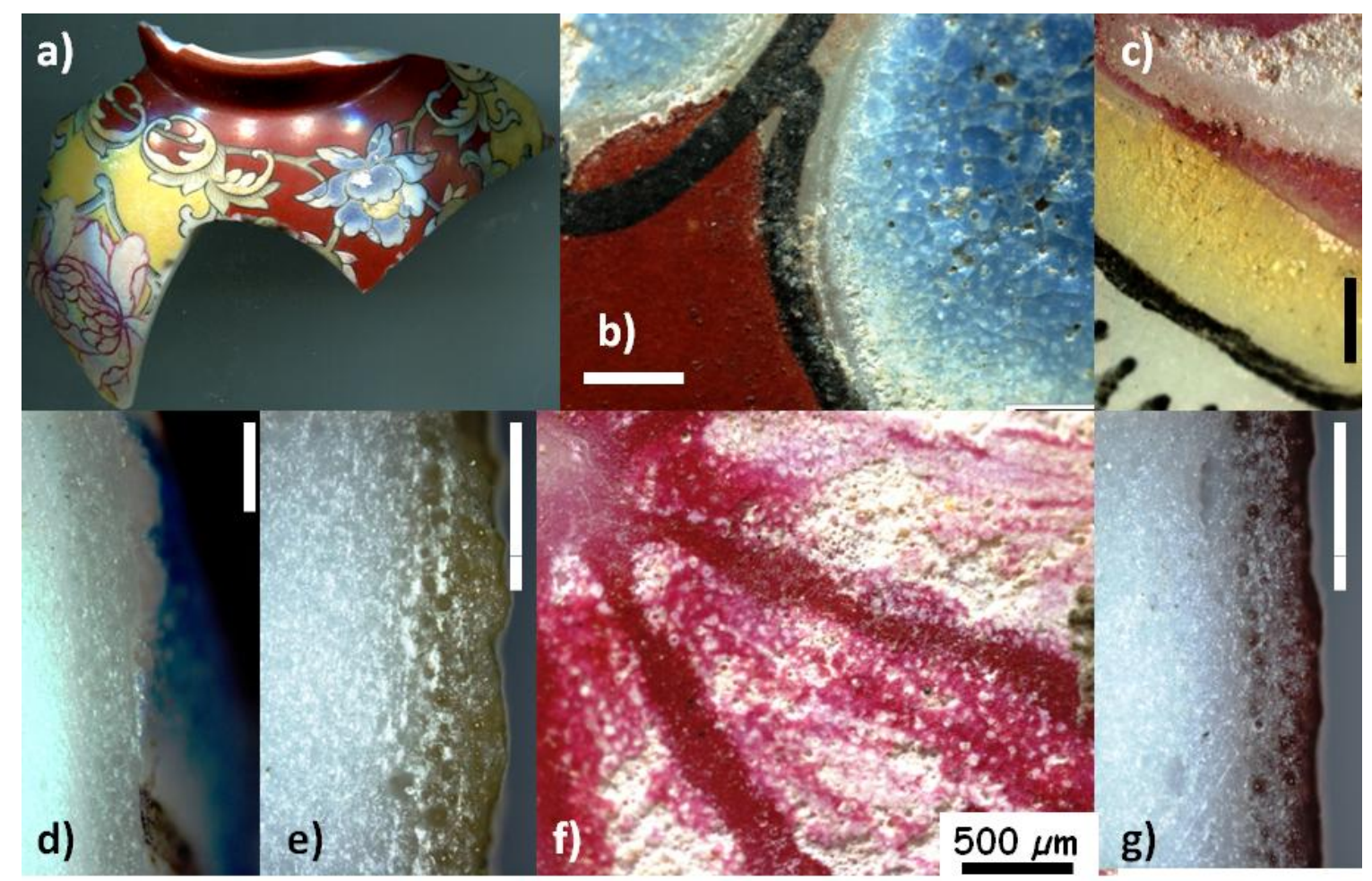

Fig. 3: doucai ware shard (a); details of the coloured areas are shown in b, c and f; sections showing the blue enamel covering the glaze $(\mathrm{d})$, the green glaze $(\mathrm{g})$ and the red enamel covering the glaze $(\mathrm{g})$, (bar $=500 \mu \mathrm{m}$, Photo Ph. Colomban). 

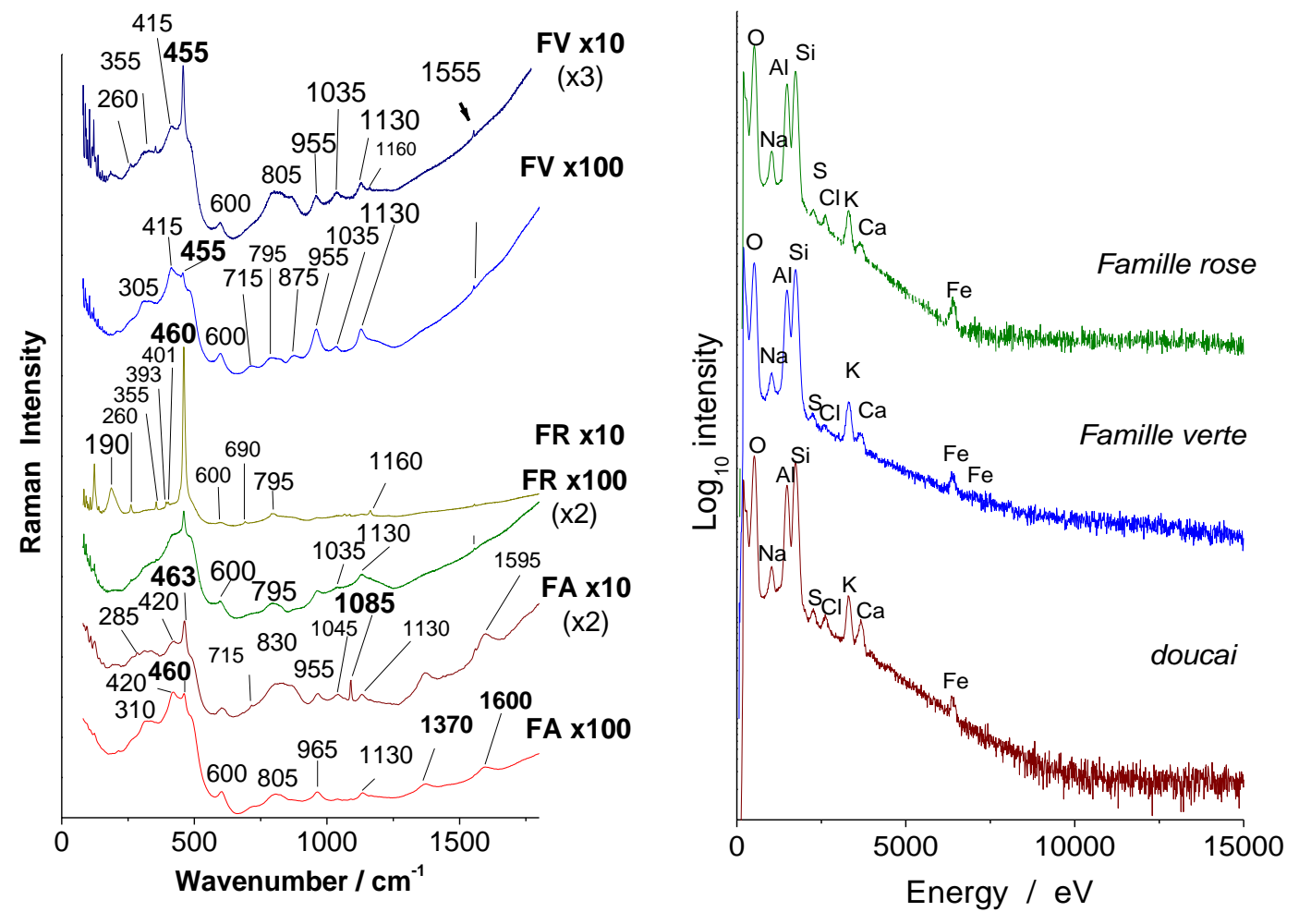

Fig. 4: Representative Raman (left) spectra of the different phases evidenced in the porcelain body and corresponding EDS spectra (right). 

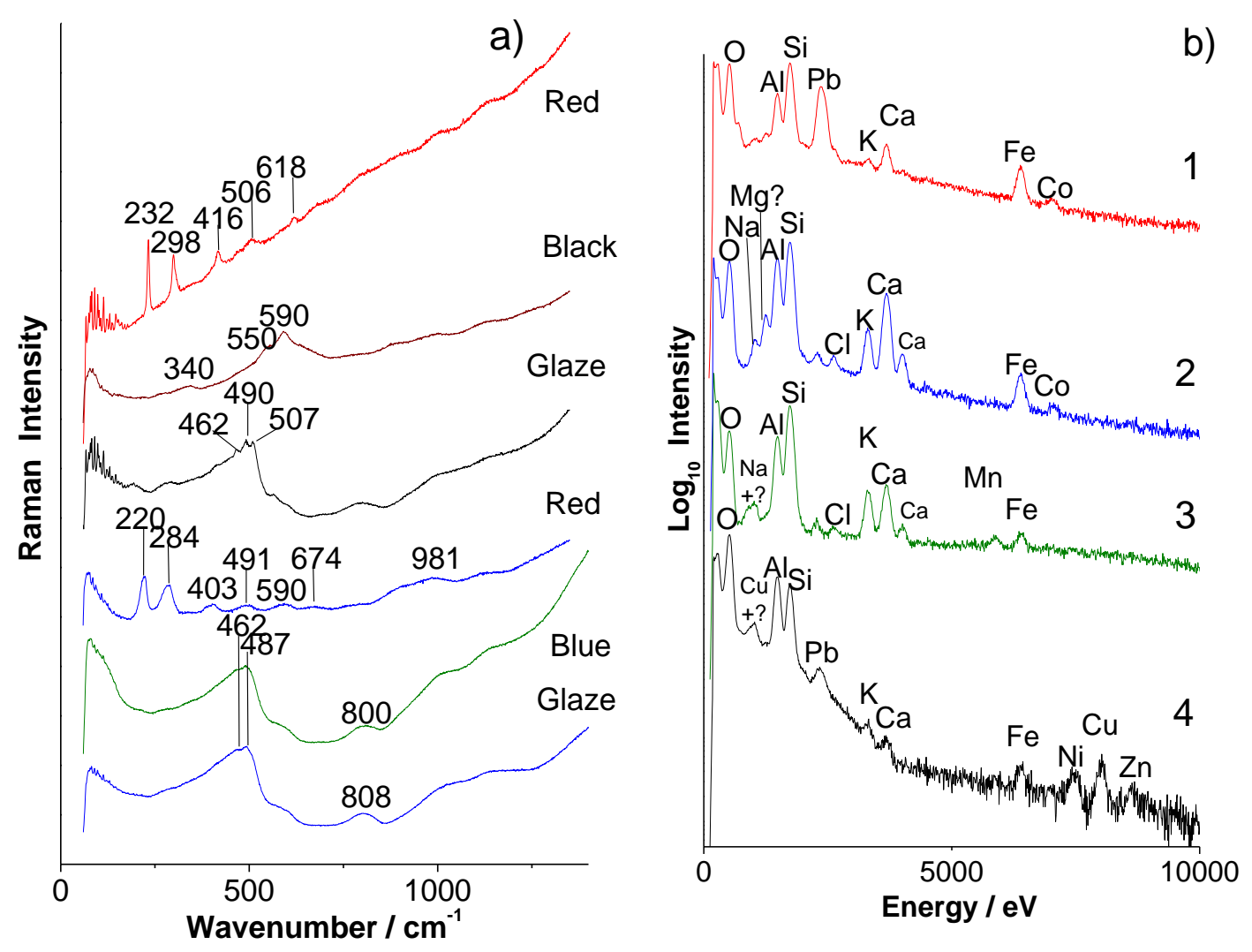

Fig. 5: Representative Raman spectra recorded on the different coloured areas of the Famille verte shard and corresponding EDS spectra: 1, blue area surface, close to the green area; 2, blue area section '(Fig. 1d); 3, black line; 4, green area overglaze (Fig. 1e). 

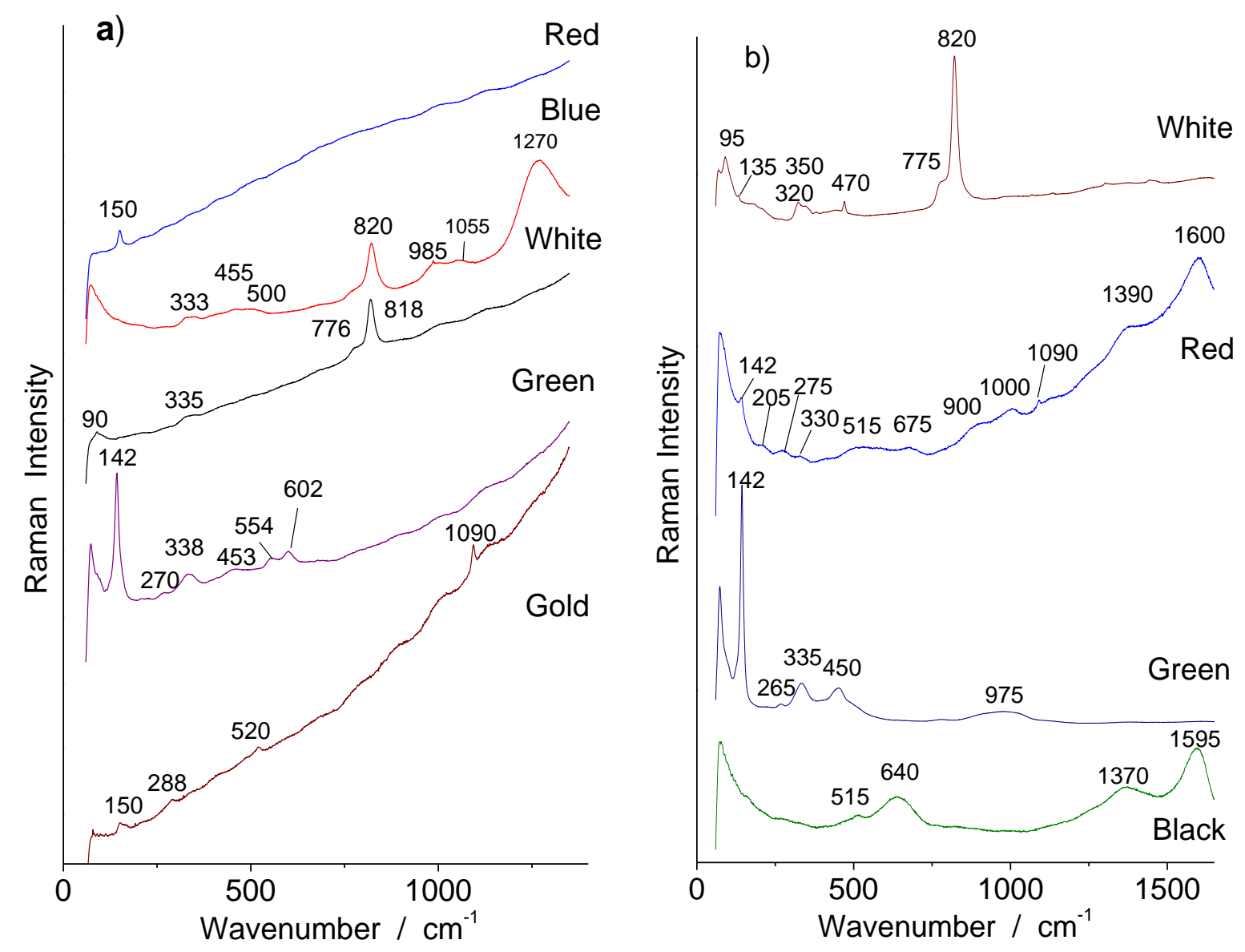

Fig. 6: Representative Raman spectra recorded on the different coloured areas of the Famille rose shard (surface analysis). 

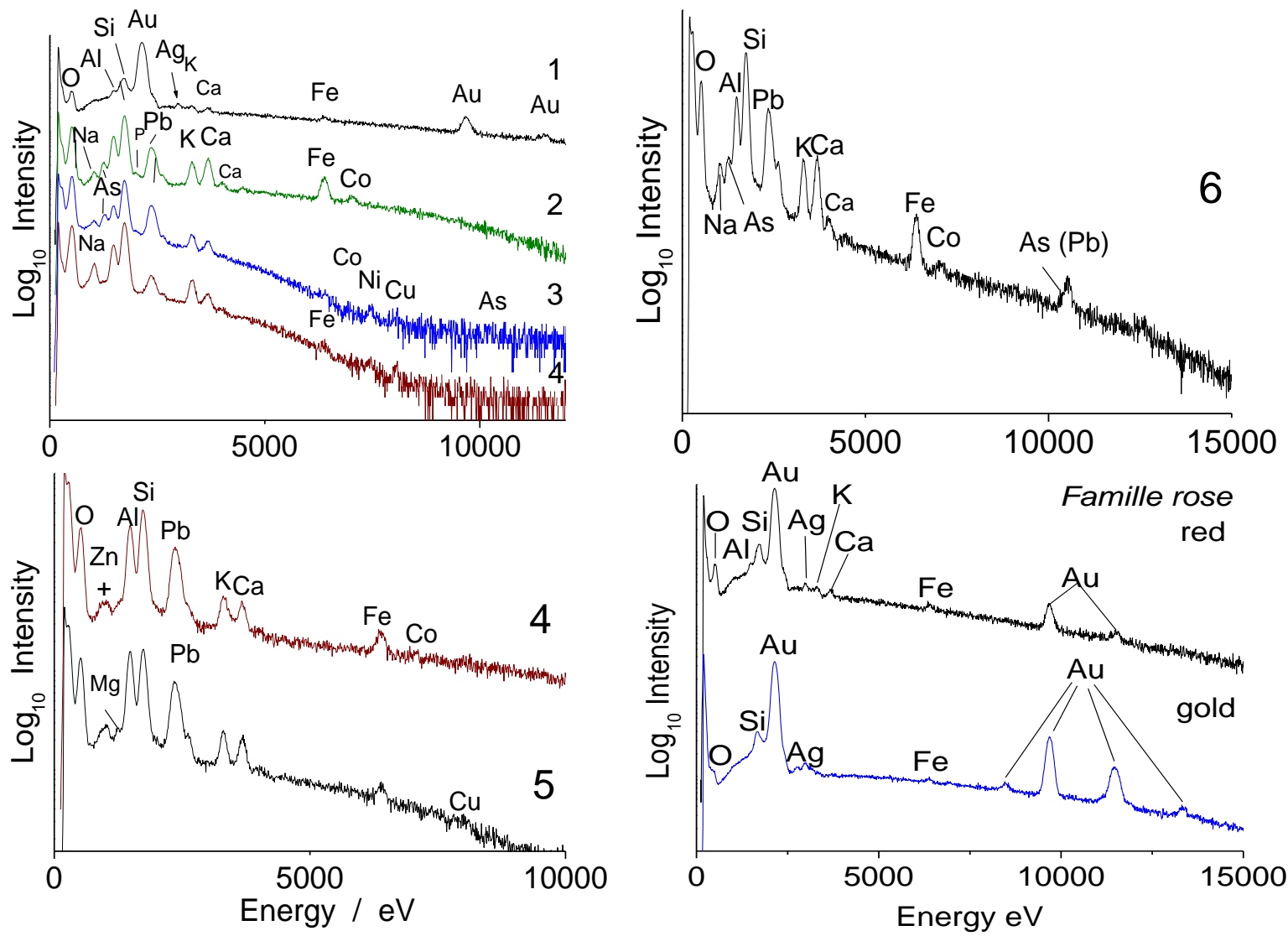

Fig. 7: Representative EDS spectra recorded on the different coloured areas of the Famille rose shard: 1 to 5 , surface analysis; 6 , section analysis (1, red area, $2 \& 4$, blue area; $3 \& 5$, green area; 6 , blue and white area; comparison between gold and 'red' areas is given, see Table 1a). 

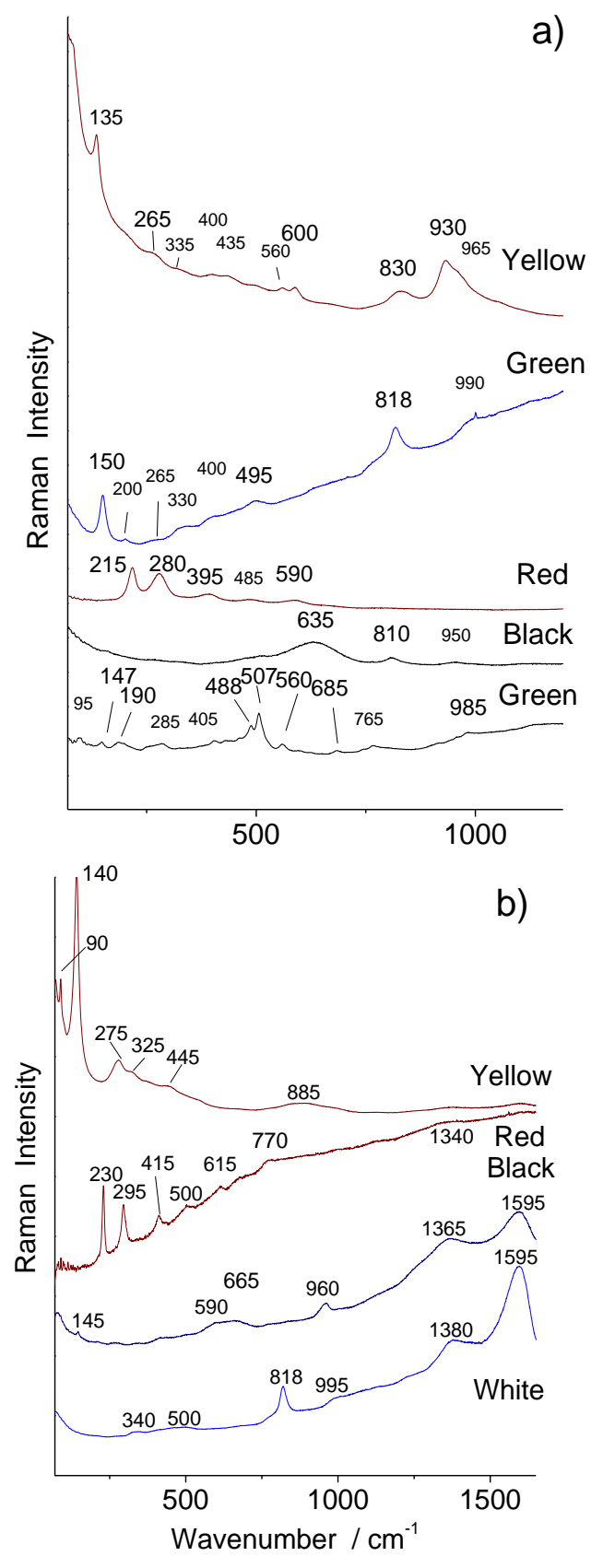

Fig. 8: Representative Raman spectra recorded on the different coloured areas of the doucai shard (a), surface analysis; b), section analysis). 

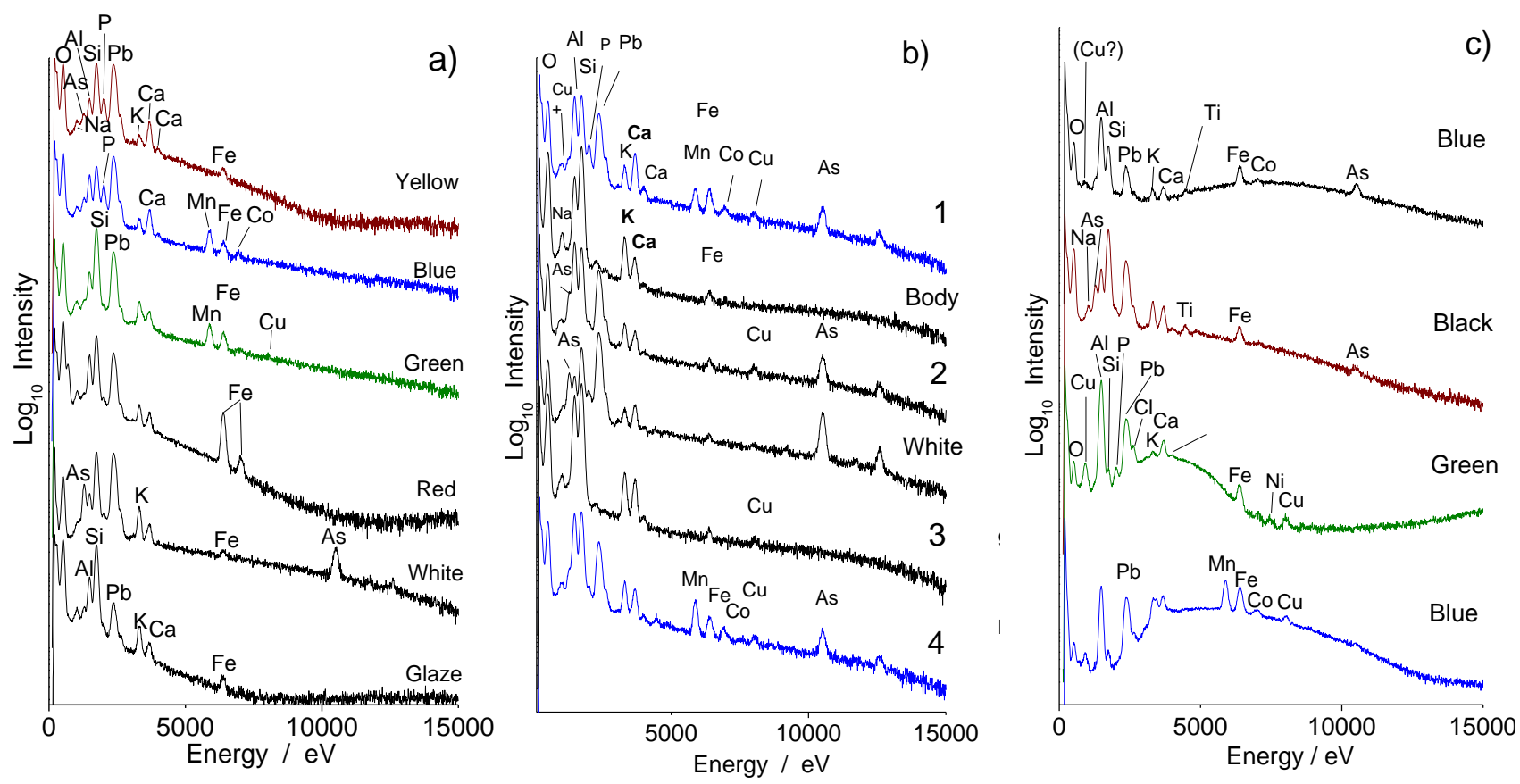

Fig. 9: Representative EDS spectra recorded on the different coloured areas of the doucai shard (a), surface analysis; b), section analysis ( $1 \& 4$, blue are; $2 \& 3$, green area; c), very local analysis). 


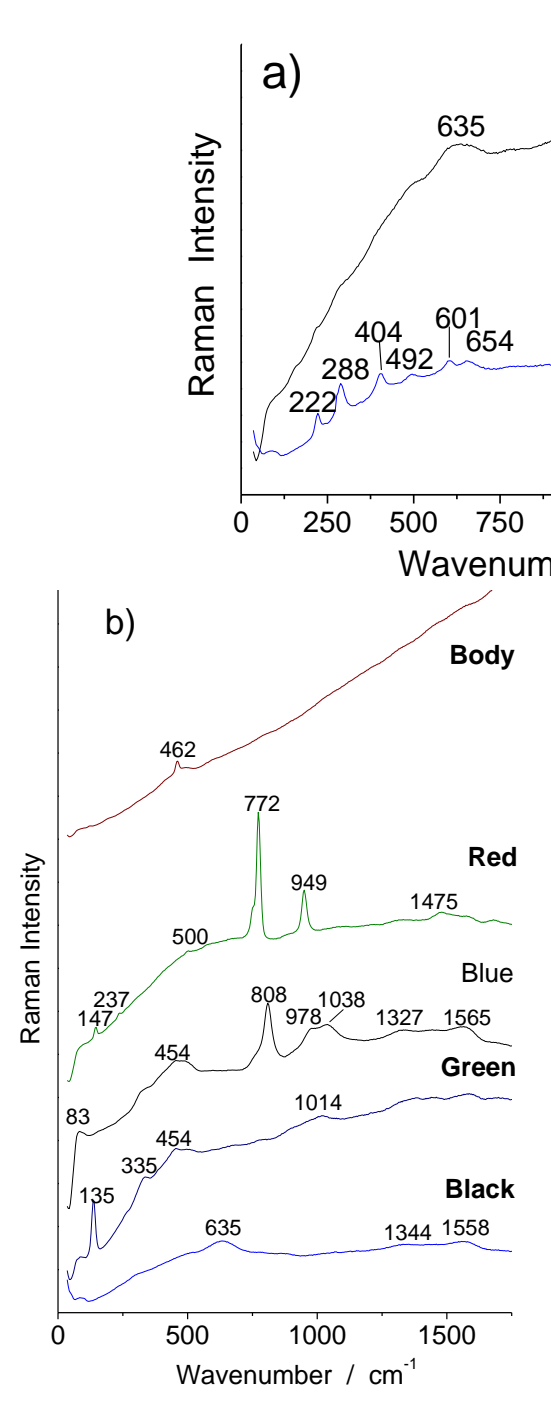

1568

Black

Red
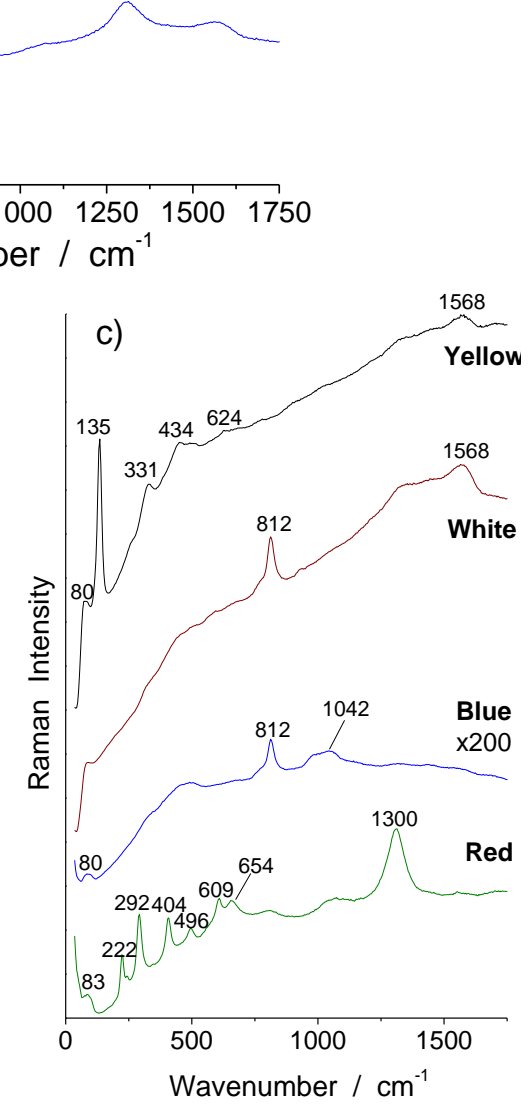

Fig.10: Representative spectra recorded with mobile HE532 Raman set-up equipped with a $\times 200$ ULWD microscope objective: a) Famille verte; b) Famille rose; c) doucai ware. 

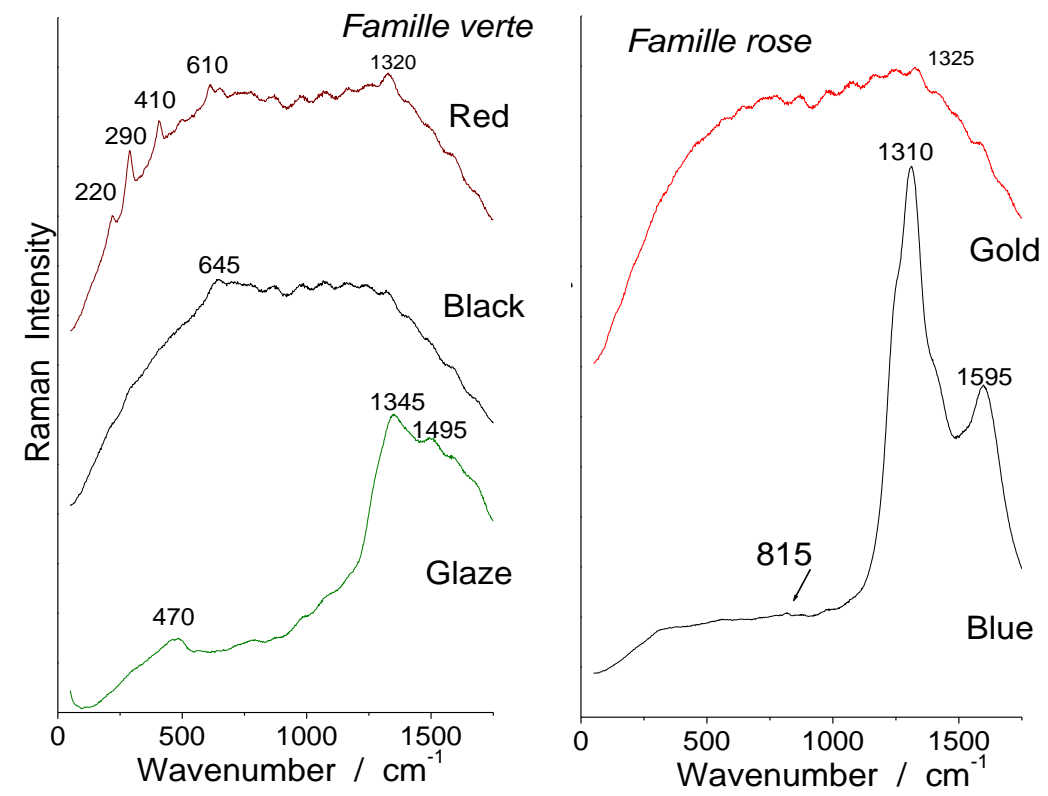

Fig. 11: Representative spectra recorded with mobile HE785 Raman set-up equipped with a x40 IR optimized LWD microscope objective. 


\section{Supplementary Materials}

Comparative analysis of wucai Chinese porcelains using mobile and fixed Raman microspectrometers

Philippe Colomban, ${ }^{1}$ Florian Ambrosi ${ }^{1}$, Anh-Tu Ngo ${ }^{1}$, Ting-An Lu ${ }^{1}$, Xiong-Lin Feng ${ }^{2}$, Stephen Chen ${ }^{3}$,Chung-Lit Choi ${ }^{3}$

${ }^{1}$ Sorbonne Universités, UPMC Univ. Paris 06, MONARIS UMR8233, 4 Place Jussieu, 75005 Paris, France

${ }^{2}$ Ancient Ceramic Research Laboratory, Chinese Academy of Science, Beijing, China

${ }^{3}$ Royal Heritage Ceramic Research Laboratory, Suit 212 Building 18, Hong Kong Science Park, Shatin, Hong Kong

Table S1: Local composition measured by EDS

$\begin{array}{llll}\text { Oxide } & \text { Famille Verte } & \text { Famille rose } & \text { Doucai ware } \\ \mathrm{SiO}_{2} & 60.71 & 62.26 & 64.45 \\ \mathrm{Al}_{2} \mathrm{O}_{3} & 32.02 & 32.32 & 28.51 \\ \mathrm{CaO} & 0.11 & 0.14 & \mathbf{0 . 4 8} \\ \mathrm{MgO} & 0.42 & - & 0.27 \\ \mathrm{~K}_{2} \mathrm{O} & 0.72 & 0.82 & 1.14 \\ \mathrm{Na}_{2} \mathrm{O} & 3.71 & 2.88 & 3.05 \\ \mathrm{Fe}_{2} \mathrm{O}_{3} & 0.20 & 0.24 & 0.16 \\ \mathrm{P}_{2} \mathrm{O}_{5} & 1.26 & 0.35 & 1.14 \\ \mathrm{NiO} & 0.06 & 0.06 & 0.03 \\ \mathrm{CuO} & 0.15 & 0.08 & 0.04 \\ \mathrm{ZnO} & 0.07 & 0.05 & 0.02 \\ \mathrm{PbO} & 0.27 & 0.49 & 0.24 \\ \mathrm{MnO}_{2} & 0.02 & 0.01 & 0.03 \\ \mathrm{CoO} & 0.01 & 0.03 & 0.01 \\ \mathrm{SnO}_{2} & 0.26 & - & 0.43 \\ \mathrm{SnO} & - & 0.27 & - \\ \mathrm{Cr}_{2} \mathrm{O}_{3} & - & 0.01 & - \\ \mathrm{As}_{2} \mathrm{O}_{5} & 0.02 & 0 & 0.01 \\ \mathrm{Total} & 100 & 100 & 100 \\ & & -: \text { not measured or below the detection limit }\end{array}$




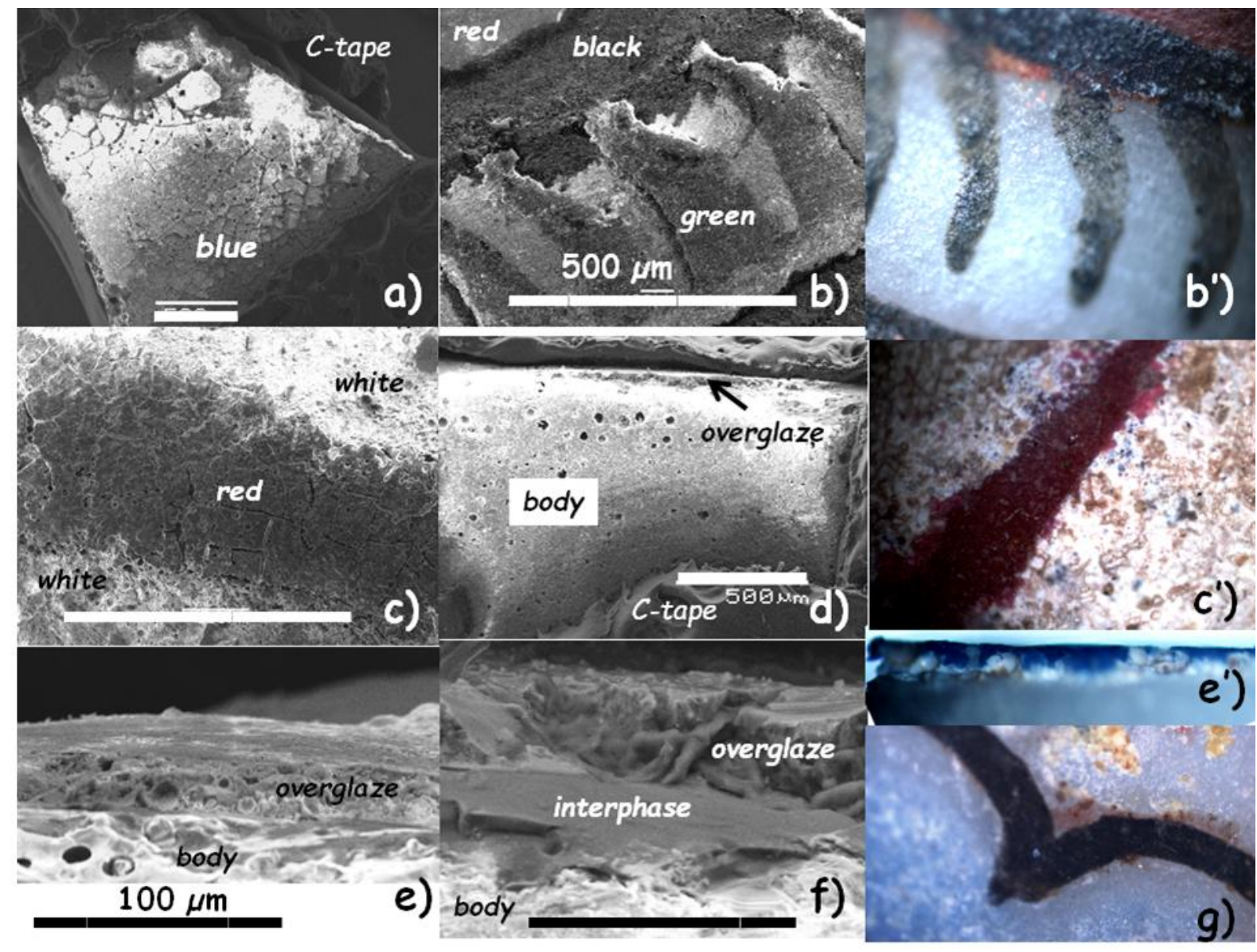

Fig. S1 a-g: Comparison between SEM (black-and-white) and optical (coloured) micrographs of the Qianlong shard: a), blue flower surface; b) \&b') stem of a leaf, surface; c) and c'), red area surface; d) to f), section showing red, yellow and blue overglazed areas (bar $=500 \mu \mathrm{m}$, except for e micrograph). 


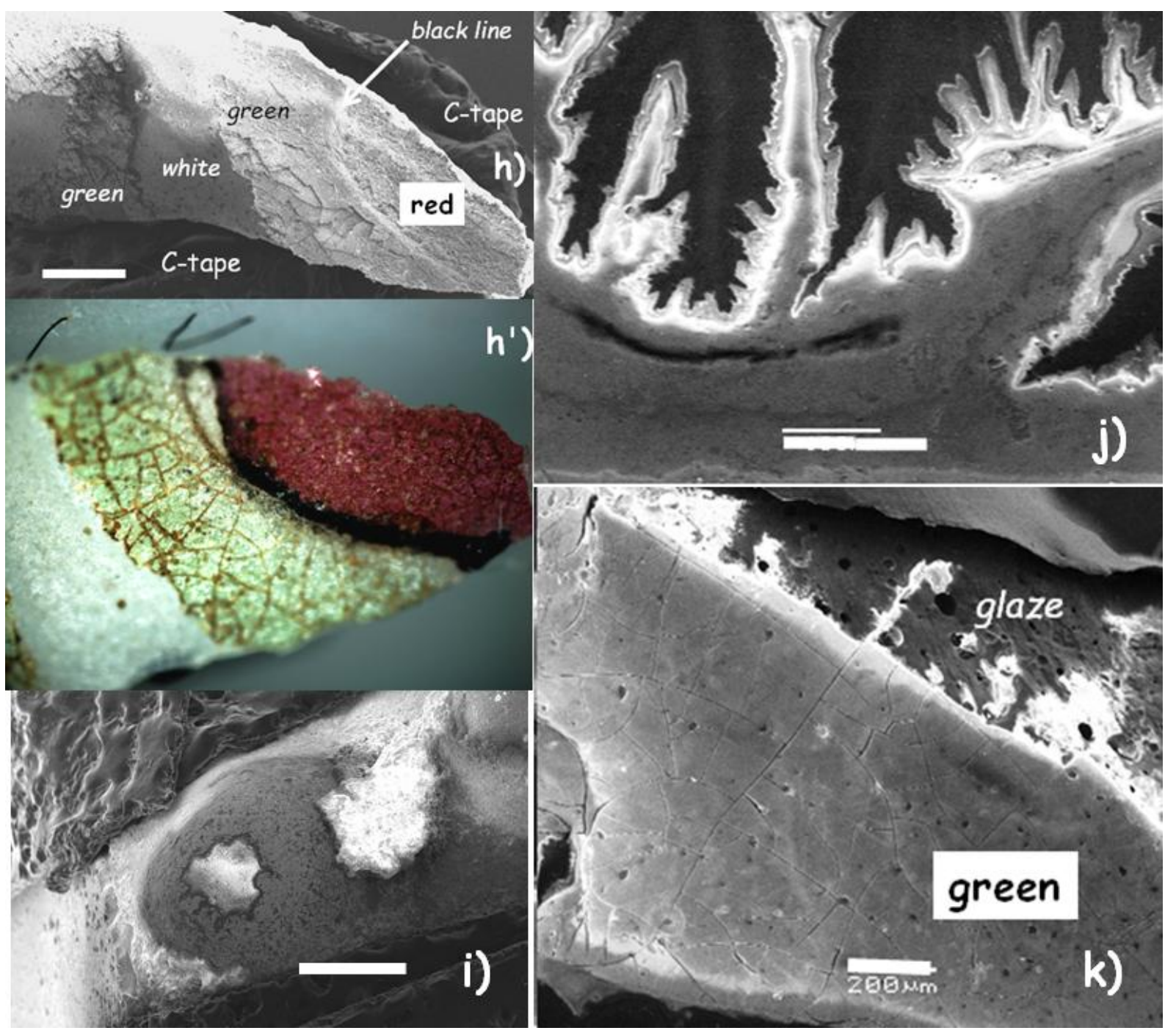

Fig. S1 h-k: Comparison between (black-and-white) SEM and optical (coloured) micrographs of the Famille rose shard: $h$ ) and $h^{\prime}$ ), zone close to the stem of a leaf, surface; i) and j), gold residues, surface; $k$ ) detail of the green overglaze (bar $=500 \mu \mathrm{m}$, except for k micrograph). 